\title{
Dalton

\section{Alkali aminoether-phenolate complexes: synthesis, structural characterization and evidence for an activated monomer ROP mechanism†}

\author{
Sorin-Claudiu Roşca, ${ }^{a}$ Dragoş-Adrian Roşca, ${ }^{a}$ Vincent Dorcet, ${ }^{a}$ Christopher M. Kozak, \\ Francesca M. Kerton, ${ }^{b}$ Jean-François Carpentier*a and Yann Sarazin*a
}

\begin{abstract}
Several monometallic $\left\{\mathrm{LO}^{i}\right\} \mathrm{M}$ complexes of lithium $(\mathrm{M}=\mathrm{Li} ; i=1$ (1), 2 (2), 3 (3)) or potassium ( $\mathrm{M}=\mathrm{K}$, $i=3(4)$ ) and the heteroleptic bimetallic lithium complex $\left\{\mathrm{LO}^{3}\right\} \mathrm{Li} \cdot \mathrm{LiN}\left(\mathrm{SiMe}_{2} \mathrm{H}\right)_{2}(\mathbf{5})$, all supported by monoanionic aminoether-phenolate $\left\{\mathrm{LO}^{i}\right\}^{-}(i=1-3)$ ligands, have been synthesized and structurally characterized. A large range of coordination motifs is represented in the solid state, depending on the chelating ability of the ligand, the size of the metal and the number of metallic centres found in the complex. Pulse-gradient spin-echo NMR showed that 1-4 are monomeric in solution, irrespective of their (mono- or di)nuclearity in the solid-state. VT ${ }^{7} \mathrm{Li}$ and DOSY NMR measurements conducted for 5 indicated that the two $\mathrm{Li}$ atoms in the complex do not exchange positions even at $80^{\circ} \mathrm{C}$. Upon addition of 1-10 equiv. of $\mathrm{BnOH}$, the electron-rich and sterically congested $\left\{\mathrm{LO}^{3}\right\} \mathrm{Li}$ complex (3) promotes the controlled living and immortal ring-opening polymerisation of L-lactide. The combination of polymer end-group analyses and stoichiometric model reactions unambiguously provided evidence that ROP reactions catalyzed by these two-component $\left\{\mathrm{LO}^{\prime}\right\} \mathrm{Li} / \mathrm{BnOH}$ catalyst systems operate according to an activated monomer mechanism, and not via the coordination-insertion scenario frequently assumed for similar alkali phenolate-alcohol systems.
\end{abstract}

Received 14th November 2012, Accepted 13th December 2012 DOI: $10.1039 / \mathrm{c} 2 \mathrm{dt} 32726 \mathrm{k}$ www.rsc.org/dalton implementation of ROP catalysts based on innocuous metals that do not impart colour to the polymer, leading to the discovery of several potent catalysts based on zinc, ${ }^{5}$ alkali ${ }^{8}$ and alkaline-earth ${ }^{9}$ metals in the past few years. In addition, the toxicity and availability of the ligand scaffold also have to be considered, and simple, robust and non-toxic ancillaries available on multi-gram scales are obviously desirable when catalyst development is concerned. In this regard, bis(phenolate) ligands have proved to be effective for the design of a large panel of ROP initiators constructed around the so-called "biometals" (Li-Na, ${ }^{8 b-h, 10} \mathrm{Mg}^{11} \mathrm{Zn}^{12}$ and $\mathrm{Ca}^{9 e}$ ). This approach was eventually epitomized by Miller and co-workers in 2012 when they revealed that BHT-supported homoleptic Li, $\mathrm{Na}, \mathrm{Mg}$ and $\mathrm{Ca}$ complexes (where BHT is butylated hydroxytoluene, a well-known antioxidant regarded as a safe additive in the food industry) competently promoted the ROP of lactide upon addition of benzyl alcohol and demonstrated that these catalysts outperformed their bridged bis(phenolate) analogues. $^{13}$

Aminophenolates constitute prime examples of readily synthesized and ubiquitous ligand scaffolds well suited to the design of ROP initiators, and as such they have enjoyed considerable attention. ${ }^{9 g, h, j, 14}$ They are easily amenable to the 
<smiles>COCCN(CCOC)Cc1cc(C(C)(C)C)cc(C(C)(C)C)c1O</smiles>

$\left\{\mathrm{LO}^{1}\right\} \mathrm{H}$<smiles>CC(C)(C)c1cc(CN2CCOCC2)cc(C(C)(C)C)c1O</smiles>

$\left\{\mathrm{LO}^{2}\right\} \mathrm{H}$<smiles>CC(C)(C)c1cc(CN2CCOCCOCCOCCOCC2)c(O)c(C(C)(C)C)c1</smiles>

$\left\{\mathrm{LO}^{3}\right\} \mathrm{H}$

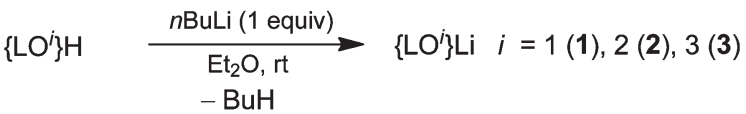

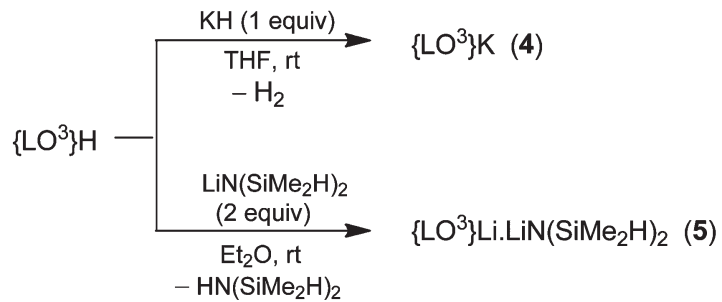

Fig. 1 Pro-ligands and corresponding alkaline complexes employed in this work.

tuning of their chelating and electron-donating properties thanks to facile functionalization at the ortho position of the aromatic ring. Their coordination chemistry is versatile, mostly because they display diverse combinations of $\mathrm{N}$ - and/or O-donor atoms that can be tuned almost at will. Some time ago, some of us introduced $\mathrm{Zn}, \mathrm{Mg}$ and $\mathrm{Ca}$ complexes which, in combination with an exogenous alcohol, afford binary catalysts exhibiting high performance in the immortal ROP $(i \mathrm{ROP})^{15}$ of L-LA, $\beta$-butyrolactone and trimethylene carbonate. $^{5 d, 16}$ These efforts were promptly emulated by the group of $\mathrm{Ma},{ }^{17}$ who achieved exceptional high activity in the controlled ROP of racemic lactide (D,L-LA) with an aminophenolate Mg complex, ${ }^{17 b}$ and by Kerton and co-workers, who used $\mathrm{Zn}$ complexes of piperazinyl-derived aminophenolate ligands to catalyse the ROP of $\varepsilon$-caprolactone (CL) and D,L-LA. ${ }^{18}$ The latter authors subsequently elaborated on their initial investigation and showed that lithium piperazinyl-aminophenolate formed cyclic trimers that efficiently polymerised CL to produce cyclic oligomers (resp. linear polymers) in the absence (resp. in the presence) of exogenous alcohol. ${ }^{8 j}$

As part of our research program aimed at implementing aminophenolate main-group metal complexes in ROP catalysis, we are introducing here the structural characterization and $i$ ROP catalytic activities of five lithium and potassium aminoether-phenolate complexes. The nature of the catalytically active species is discussed and we provide experimental evidence showing that in the presence of $\mathrm{BnOH}$, these alkali-based two-component catalysts operate according to the so-called activated monomer mechanism.

\section{Results and discussion}

\section{Syntheses and characterization}

The complexes $\left\{\mathrm{LO}^{1}\right\} \mathrm{Li}(\mathbf{1}),\left\{\mathrm{LO}^{2}\right\} \mathrm{Li}(2)$ and $\left\{\mathrm{LO}^{3}\right\} \mathrm{Li}(3)$ were isolated as mildly air-sensitive colourless solids in non-optimized 50-95\% yield upon stoichiometric reaction of the corresponding pro-ligands $\left\{\mathrm{LO}^{i}\right\} \mathrm{H}^{16,19}$ with $n \mathrm{BuLi}$ in $\mathrm{Et}_{2} \mathrm{O}$ (Fig. 1). Complexes $\mathbf{1}$ and $\mathbf{3}$ are fully soluble and stable over periods of days in chlorinated solvents (chloroform, dichloromethane), and are also soluble in aromatic hydrocarbons. At room temperature, the ${ }^{1} \mathrm{H}$ NMR data of 3 in benzene- $\mathrm{d}_{6}$ showed several multiplets with good resolution, but the ${ }^{1} \mathrm{H}$ NMR spectra of 1 in this solvent or in dicholoromethane- $\mathrm{d}_{2}$ only revealed broad resonances for the aminoether side-arms from which no information regarding the structure of the complex could be gained; low temperature ${ }^{1} \mathrm{H}$ NMR did not provide substantial improvement. Their ${ }^{7} \mathrm{Li}$ NMR spectra recorded in benzene$\mathrm{d}_{6}$ are characterized by a single, sharp resonance at $\delta_{\mathrm{Li}}$ $0.99 \mathrm{ppm}$ (for 1) and $0.07 \mathrm{ppm}$ (for 3), consistent with the increase of electron density at the metal centre on moving from 1 to 3 . Single-crystals of these complexes suitable for $\mathrm{X}$-ray diffraction studies were readily grown from $\mathrm{Et}_{2} \mathrm{O}$-pentane mixtures. On the other hand, 2 is only sparingly soluble in hydrocarbons and diethyl ether, moderately so in chlorinated solvents and it can only be adequately dissolved in THF. The colourless potassium complex $\left\{\mathrm{LO}^{3}\right\} \mathrm{K}(\mathbf{4})$ was prepared quantitatively by an equimolar reaction of $\left\{\mathrm{LO}^{3}\right\} \mathrm{H}$ and $\mathrm{KH}$ in THF; its solubility is poor even in $\mathrm{Et}_{2} \mathrm{O}$ and chlorinated solvents, and it can only be fully dissolved in $\mathrm{THF}^{20}$ The heteroleptic bimetallic $\left\{\mathrm{LO}^{3}\right\} \mathrm{Li} \cdot \mathrm{LiN}\left(\mathrm{SiMe}_{2} \mathrm{H}\right)_{2}(5)$ was obtained 
in $70 \%$ yield upon addition of 2 equiv. of $\operatorname{LiN}\left(\mathrm{SiMe}_{2} \mathrm{H}\right)_{2}$ to a solution of $\left\{\mathrm{LO}^{3}\right\} \mathrm{H}$ in $\mathrm{Et}_{2} \mathrm{O}$; its solubility in all common organic solvents was excellent, and X-ray quality crystals were readily obtained by recrystallization from a 1:5 mixture of $\mathrm{Et}_{2} \mathrm{O}$ and pentane. In contrast to its potassium congener $\left\{\mathrm{LO}^{3}\right\} \mathrm{K} \cdot \mathrm{KN}\left(\mathrm{SiMe}_{2} \mathrm{H}\right)_{2},{ }^{14 e}$ there is no spectroscopic evidence for the presence of $\mathrm{M} \cdots \mathrm{H}-\mathrm{Si}$ agostic bonding in $\mathbf{5}(\mathrm{M}=\mathrm{Li})$, as indicated by the rather large value of ${ }^{1} J_{\mathrm{SiH}}$ coupling constant $(166.5 \mathrm{~Hz})$ in its ${ }^{1} \mathrm{H}$ NMR spectrum recorded at $233 \mathrm{~K}$ and by the presence of a single, broad band corresponding to the stretching frequency of the $\mathrm{Si}-\mathrm{H}$ bond at $1992 \mathrm{~cm}^{-1}$ in its FTIR spectrum. These observations were subsequently corroborated by examination of the solid-state structure of $\mathbf{5}$ (vide infra). The ${ }^{1} \mathrm{H}$ NMR spectrum of 5 recorded at $298 \mathrm{~K}$ features dynamic behaviour for all hydrogens belonging to the azacrown-ether fragment and contains a unique, somewhat broad singlet for the two $\mathrm{Si}\left(\mathrm{CH}_{3}\right)_{2} \mathrm{H}$ groups. The fluxionality in the heterocyclic side-arm can be frozen effectively at $233 \mathrm{~K}$. At this temperature, two distinct singlets are detected for the $\mathrm{Si}\left(\mathrm{CH}_{3}\right)_{2} \mathrm{H}$ hydrogens; coalescence of the two singlets is observed at $273 \mathrm{~K}$. At $298 \mathrm{~K}$, the ${ }^{7} \mathrm{Li}$ NMR spectrum of 5 exhibits two sharp singlets at $\delta_{\mathrm{Li}} 1.14$ and $-0.46 \mathrm{ppm}$, indicative of two non-equivalent environments for the lithium atoms; this was subsequently confirmed by crystallographic investigations (vide infra). No sign of dynamic exchange between the two $\mathrm{Li}$ atoms was detected in the temperature range 233-353 K, as the presence of two well-resolved singlets persisted even at elevated temperature; evidently each Li centre is firmly settled in its own coordination environment. The $\left\{{ }^{1} \mathrm{H}{ }^{29} \mathrm{Si}\right.$ NMR spectrum of 5 recorded in benzene- $\mathrm{d}_{6}$ at $298 \mathrm{~K}$ features a sharp singlet at $\delta_{\mathrm{Si}}-27.9 \mathrm{ppm}$, i.e. at a much higher field than found in the comparatively electron-poor LiN$\left(\mathrm{SiMe}_{2} \mathrm{H}\right)_{2}\left(\delta_{\mathrm{Si}}-22.0 \mathrm{ppm}\right)$ and in the parent amine $\mathrm{HN}$ $\left(\mathrm{SiMe}_{2} \mathrm{H}\right)_{2}\left(\delta_{\mathrm{Si}}-11.5 \mathrm{ppm}\right)$, but at higher frequency than identified in $\left\{\mathrm{LO}^{3}\right\} \mathrm{K} \cdot \mathrm{KN}\left(\mathrm{SiMe}_{2} \mathrm{H}\right)_{2}\left(\delta_{\mathrm{Si}}-31.2 \mathrm{ppm}\right),{ }^{14 e}$ as expected on account of the more ionic nature of the $\mathrm{M} \cdots \mathrm{N}$ bond in this last complex $(\mathrm{M}=\mathrm{K})$ than in $\mathbf{5}(\mathrm{M}=\mathrm{Li})$. Beyond their ability to promote ROP reactions (vide infra), the salts 1-5 have previously proved to be valuable reagents in the syntheses of a variety of alkaline-earth and group 14 metal complexes involving salt metathesis reactions. ${ }^{5 d, 14 e, g, 16,21}$

Single-crystals of the dimeric $(\mathbf{1})_{2}$ were grown from a cold solution of $\mathbf{1}$ in a pentane- $\mathrm{Et}_{2} \mathrm{O}$ mixture, and their solid-state structure was elucidated (Fig. 2). The dimer contains a $C_{2}$ axis passing through the centre of the planar $\mathrm{Li}_{2} \mathrm{O}_{2}$ core. Each metal centre is 4-coordinate and exists in a distorted tetrahedral environment. The two metals are bridged by the $\mathrm{O}_{\text {phenolate }}$ atoms with $\mathrm{Li}-\mathrm{O}_{\text {phenolate }}$ distances in the range 1.85-1.90 $\AA$, and the coordination sphere for a given lithium is completed by the $\mathrm{N}_{\text {amine }}$ and one $\mathrm{O}_{\text {ether }}$ atom of the same phenolate ligand. Unexpectedly, the second chelating $\mathrm{O}_{\text {ether }}$ side-arm does not interact with the metal centres, and each ancillary amino-ether phenolate therefore acts as a $\mu^{2}: \kappa^{3}, \kappa^{1}$ chelating ligand. The $\mathrm{Li} \cdots \mathrm{O}_{\text {ether }}$ distance to the coordinated ether side-arm $(2.01 \AA)$ is significantly greater than that to the bridging $\mathrm{O}_{\text {phenolate }}$ atoms.

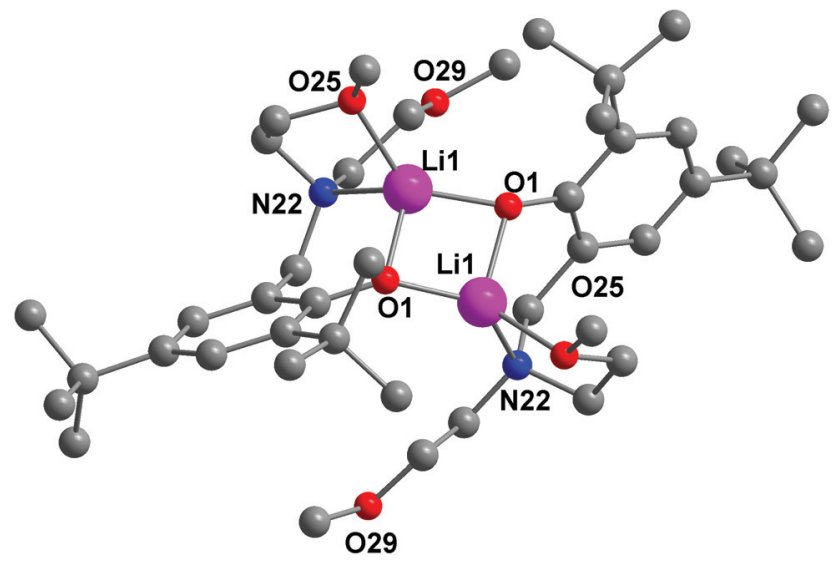

Fig. 2 Representation of the solid-state structure of $(\mathbf{1})_{2}$. Hydrogen atoms are omitted for clarity. Selected bond lengths $(\AA \AA)$ and bond angles $\left(^{\circ}\right)$ : O(1)-Li(1) 1.849(5), O(1)-Li(1) 1.900(4), Li(1)-O(25) 2.009(5), Li(1)-N(22) 2.102(5), Li(1)$\mathrm{Li}(1)^{\# 1}$ 2.465(9); Li(1)-O(1)-Li(1)\#1 82.2(2), O(1)-Li(1)-O(1)\#1 97.2(2), O(1)-Li(1)$\mathrm{O}(1)^{\# 1} \quad 97.2(2), \quad \mathrm{O}(1)-\mathrm{Li}(1)-\mathrm{O}(25)^{\# 1} \quad 131.9(2), \quad \mathrm{O}(1)-\mathrm{Li}(1)-\mathrm{N}(22)^{\# 1}$ 127.2(2), $\mathrm{O}(1)^{\# 1}-\mathrm{Li}(1)-\mathrm{N}(22)^{\# 1} 98.3(2), \mathrm{O}(25)^{\# 1}-\mathrm{Li}(1)-\mathrm{N}(22)^{\# 1} 84.6(2)$.

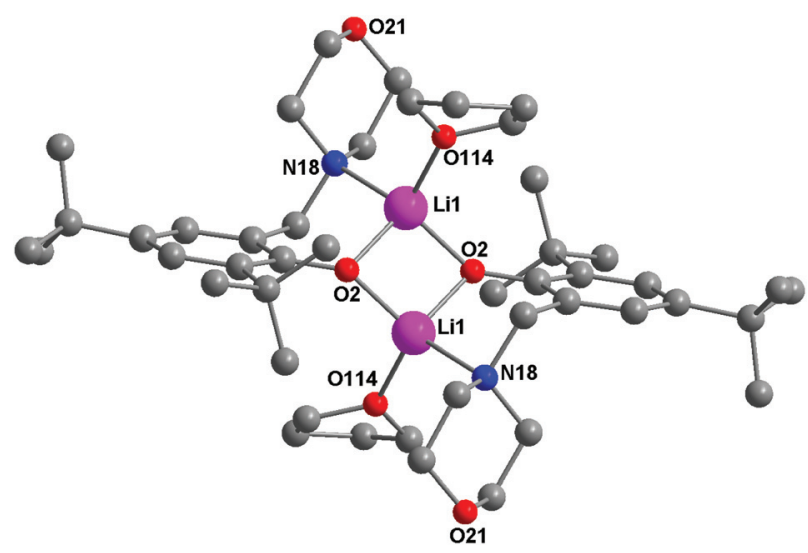

Fig. 3 Representation of the solid-state structure of (2-THF $)_{2}$; only one of the two molecules of (2-THF $)_{2}$ is depicted. Hydrogen atoms are omitted for clarity. Selected bond lengths $(\AA)$ and bond angles $\left({ }^{\circ}\right)$ : $\mathrm{Li}(1)-\mathrm{O}(2)$ 1.918(4), $\mathrm{Li}(1)-\mathrm{O}(2)^{\# 1}$ 1.931(4), Li(1)-O(114) 1.968(4), Li(1)-N(18) 2.252(4), Li(1)-Li(1) 2.576(7); O (2)-Li(1)-O(2)\#1 95.98(17), O(2)-Li(1)-O(114) 109.98(19), O(2) \#1-Li(1)-O(114) 118.85(19), O(2)-Li(1)-N(18)\#1 124.83(19), O(2) ${ }^{\# 1}-\mathrm{Li}(1)-\mathrm{N}(18)^{\# 1}$ 98.48(16), O (114)-Li(1)-N(18) $108.51(17), \mathrm{Li}(1)-\mathrm{O}(2)-\mathrm{Li}(1)^{\# 1} 84.02(17)$.

Recrystallization of 2 in THF-pentane yielded crystals of the dimeric THF-adduct $(2 \cdot \mathbf{T H F})_{2}$. Each asymmetric unit contains two independent but essentially identical molecules, and only one of them is represented in Fig. 3. The $\mathrm{Li}_{2} \mathrm{O}_{2}$ central core is planar and the two halves of the molecule are related by a crystallographic inversion centre; the two Li atoms are connected by bridging $\mathrm{O}_{\text {phenolate }}$ atoms that are located at $c a$. $1.92 \AA$ from the metal centres, i.e. a little further than found in $(\mathbf{1})_{2}$. Each Li centre, which lies in a pseudo-tetrahedral arrangement, is also coordinated by a molecule of THF and by the $\mathrm{N}_{\text {amine }}$ atom of the morpholine tether. The $\mathrm{Li} \cdots \mathrm{N}_{\text {amine }}$ bond length in 


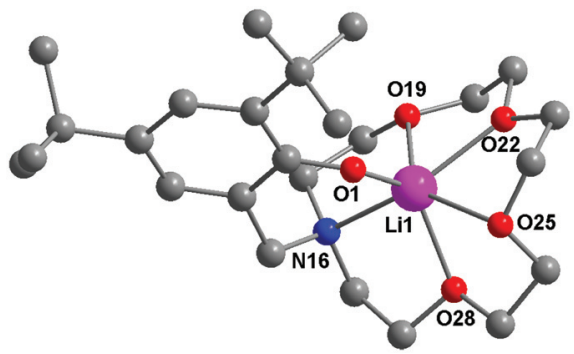

Fig. 4 Representation of the solid-state structure of 3. Hydrogen atoms are omitted for clarity. Selected bond lengths $(\AA)$ and bond angles $\left({ }^{\circ}\right)$ : $\mathrm{Li}(1)-\mathrm{O}(1)$ 1.841(2), O(19)-Li(1) 2.288(3), O(22)-Li(1) 2.189(2), O(25)-Li(1) 2.421(3), Li(1)$\mathrm{O}(28)$ 2.187(2), Li(1)-N(16) 2.278(3); O(22)-Li(1)-N(16) 143.04(13), O(19)-Li(1)$\mathrm{O}(25)$ 137.91(10), O(1)-Li(1)-O(28) 127.59(13).

$(\mathbf{2} \cdot \mathbf{T H F})_{2}(2.25 \AA)$ is substantially larger than in $(\mathbf{1})_{2}(2.10 \AA)$, most probably because of repulsive steric interactions between the morpholine rings (which retain the original boat conformation divulged in $\left.\left\{\mathrm{LO}^{2}\right\} \mathrm{H}\right)^{16}$ and the coordinated THF molecules.

Less characteristically for the small lithium atom, the metal centre is 6-coordinate in 3 (Fig. 4). In addition to the tightly coordinated $\mathrm{O}_{\text {phenolate }}$ atom $\left(\mathrm{Li}-\mathrm{O}_{\text {phenolate }}=1.84 \AA\right)$, all $\mathrm{N}_{\text {amine }}$ and $\mathrm{O}_{\text {ether }}$ atoms of the anchored aza-crown-ether bind rather loosely to the metal with $\mathrm{Li}$...h heteroatom distances in the range 2.19-2.42 $\AA$. The ancillary ligand thus forms a $\kappa^{6}$-chelate. The $\mathrm{Li} \cdots \mathrm{O}_{\text {phenolate }}$ bond length in 3 is noticeably shorter than in the dimeric $(\mathbf{1})_{2}$ and $(\mathbf{2} \cdot \mathbf{T H F})_{2}$, but it is rigorously identical to that reported for the cyclic trimer $\left(\mathrm{Li}\left\{\mathrm{ONN}^{\mathrm{Me}, t \mathrm{Bu}}\right\}\right)_{3}$ complex incorporating a bulky $\left\{\mathrm{ONN}^{\mathrm{Me}, t \mathrm{Bu}}\right\}^{-}$ piperazinyl-aminophenolate ligand; ${ }^{8 j}$ yet, the $\mathrm{Li} \cdots \mathrm{N}_{\text {amine }}$ length in this latter complex $(2.10 \AA)$ is markedly smaller than in 3 (2.28 ̊).

By comparison, the related potassium complex $(4)_{2}$ was obtained as a dimer upon recrystallization of $\mathbf{4}$ from a concentrated solution in $\mathrm{Et}_{2} \mathrm{O}$. Complex $(4)_{2}$ contains a central nonplanar $\mathrm{K}_{2} \mathrm{O}_{2}$ core exhibiting a $C_{2}$ symmetry axis, with $\mathrm{O}_{\text {phenolate }}$ atoms in bridging positions (Fig. 5). The large metal centres are 7-coordinate, with an arrangement where the aminoetherphenolates act as $\mu^{2}: \kappa^{6}, \kappa^{1}$ chelating ligands. For a given potassium atom $i$, the dissymmetry between the two $\mathrm{K}(i) \cdots \mathrm{O}_{\text {phenolate }}$ distances is moderate, with discrepancies of ca. $0.03-0.10 \AA$ between the $\mathrm{K}(i)-\mathrm{O}(1)$ and $\mathrm{K}(i)-\mathrm{O}(2)$ bond lengths found in the range $2.58-2.68 \AA$. The $\mathrm{O}_{\text {ether }}$ atoms from the aza-crown-ether side-arm are more remote, with $\mathrm{K}(i) \cdots \mathrm{O}_{\text {ether }}$ distances between 2.78 and $3.03 \AA$. Note that while in 3 the small lithium atom fits adequately in the aza-crownether ring (the distance from $\mathrm{Li}$ to the mean plane formed by the $\mathrm{N}_{\text {amine }}$ and the four $\mathrm{O}_{\text {ether }}$ atoms being only $0.64 \AA$ ), the potassium atoms in $(\mathbf{4})_{2}$ are too voluminous to enter the heterocyclic pockets and instead rest $1.63 \AA$ above the mean plane formed by the heteroatoms. Unlike in $\left\{\mathrm{LO}^{3}\right\} \mathrm{K} \cdot \mathrm{KN}-$ $\left(\mathrm{SiMe}_{2} \mathrm{H}\right)_{2},{ }^{14 e}$ there is no $\pi$-arene $\cdots \mathrm{K}$ interaction in $\mathbf{4}$.

The bimetallic $\left\{\mathrm{LO}^{3}\right\} \mathrm{Li} \cdot \mathrm{LiN}\left(\mathrm{SiMe}_{2} \mathrm{H}\right)_{2}$ (5) displays remarkable coordination modes in the solid state, as depicted in

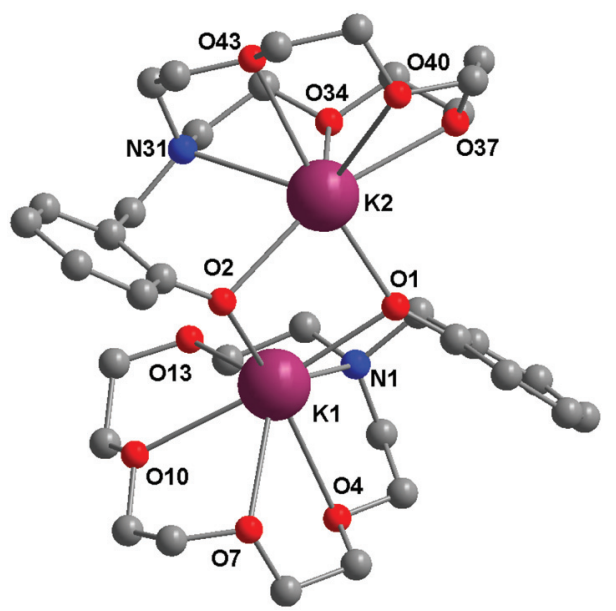

Fig. 5 Representation of the solid-state structure of $(\mathbf{4})_{2}$; only the main component of the disordered o- $\mathrm{C}\left(\mathrm{CH}_{3}\right)_{3}$ group is represented. Hydrogen atoms and tBu groups omitted for clarity. Selected bond lengths $(\AA)$ and bond angles $\left({ }^{\circ}\right)$ : K (1) $-\mathrm{O}(2) 2.622(1), \mathrm{K}(1)-\mathrm{O}(1) 2.653(1), \mathrm{K}(1)-\mathrm{O}(7) 2.790(1), \mathrm{K}(1)-\mathrm{O}(10) 2.881(1), \mathrm{K}$ (1)-O(13) 2.891(1), K(1)-N(1) 2.950(1), K(1)-O(4) 3.034(1), K(1)-K(2) 3.821(5), $\mathrm{K}(2)-\mathrm{O}(1) \quad 2.581(1), \quad \mathrm{K}(2)-\mathrm{O}(2) \quad 2.678(1), \quad \mathrm{K}(2)-\mathrm{O}(34) \quad 2.784(2), \quad \mathrm{K}(2)-\mathrm{O}(37)$ $2.809(1), \quad K(2)-N(31) \quad 2.923(1), \quad K(2)-O(43) \quad 2.941(1), \quad K(2)-O(40) \quad 2.983(1)$; $\mathrm{O}(2)-\mathrm{K}(1)-\mathrm{O}(1) 81.27(4), \mathrm{K}(1)-\mathrm{O}(2)-\mathrm{K}(2) 92.26(4), \mathrm{K}(2)-\mathrm{O}(1)-\mathrm{K}(1) 93.76(4)$.

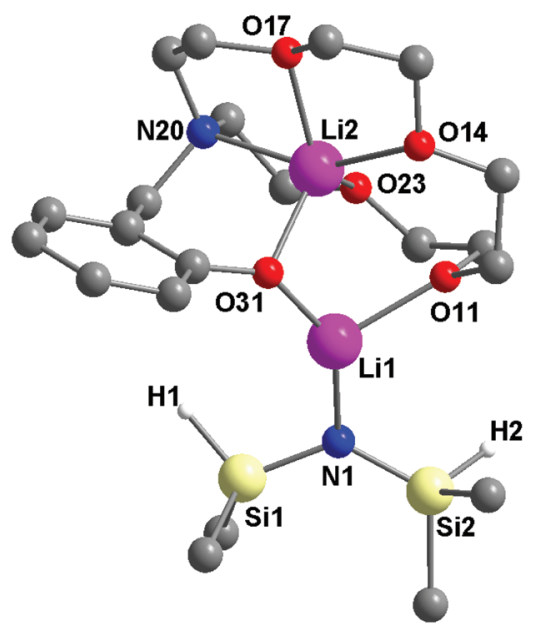

Fig. 6 Representation of the solid-state structure of $\mathbf{5}$; the two components of the disordered $\mathrm{Si}\left(\mathrm{CH}_{3}\right)_{2} \mathrm{H}$ group (on $\mathrm{Si}(2)$ ) are depicted. Hydrogen atoms and $\mathrm{C}$ $\left(\mathrm{CH}_{3}\right)_{3}$ groups in ortho and para positions of the aromatic ring are omitted for clarity. Selected bond lengths $(\AA)$ and bond angles $\left({ }^{\circ}\right)$ : $\mathrm{Li}(1)-\mathrm{O}(31) 1.827(2)$, Li (1)-N(1) 1.961(3), Li(1)-O(11) 2.056(2), Li(1)-Li(2) 2.795(3), Li(2)-O(31) 1.941 (2), $\mathrm{Li}(2)-\mathrm{O}(17) 2.105(2), \mathrm{Li}(2)-\mathrm{O}(14) 2.214(3), \mathrm{Li}(2)-\mathrm{N}(20) 2.216(3), \mathrm{Li}(2)-\mathrm{O}(23)$ 2.219(2); $\mathrm{Si}(2)-\mathrm{N}(1)-\mathrm{Si}(1)$ 129.22(7), Si(2)-N(1)-Li(1) 116.73(10), Si(1)-N(1)-Li(1) 110.60(9), Li(1)-O(31)-Li(2) 95.70(11), O(17)-Li(2)-O(23) 125.99(12), O(14)-Li $(2)-\mathrm{N}(20)$ 153.24(12), O(31)-Li(1)-N(1) 145.24(14), O(31)-Li(1)-O(11) 100.78 (11), N(1)-Li(1)-O(11) 113.70(12).

Fig. 6. Overall, the aminoether-phenolate $\left\{\mathrm{LO}^{3}\right\}^{-}$in 5 binds to the two Li centres in a highly unusual $\mu^{2}: \kappa^{5}, \kappa^{2}$ fashion. The $\mathrm{O}_{\text {phenolate }}$ atom bridges the two metals, albeit in a rather dissymmetric fashion; the $\mathrm{Li}(1)-\mathrm{O}(31)(1.83 \AA)$ and $\mathrm{Li}(2)-\mathrm{O}(31)$ (1.94 ̊̊) lengths resemble that found in $3(1.84 \AA)$. The Li $(2)$ atom is 5 -coordinate, having in addition to $\mathrm{O}_{\text {phenolate }}$ its 
Table 1 PGSE NMR measurements (298 K) and X-ray crystallographic data for 1, 2 and $\mathbf{4}$

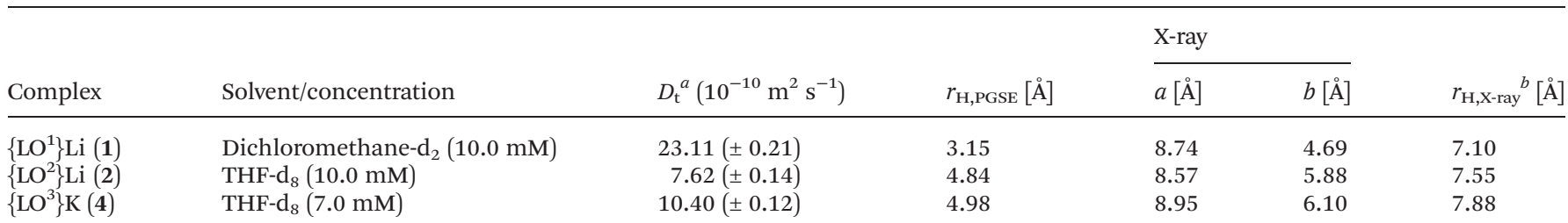

${ }^{a}$ Average of the values of $D_{\mathrm{t}}$ found for 3 or more separate peaks in the ${ }^{1} \mathrm{H}$ PGSE NMR spectrum. ${ }^{b}$ Calculated according to $r_{\mathrm{H}, \mathrm{X} \text {-ray }}=\left(a^{2} b\right)^{1 / 3}$ where $a$ and $b$, respectively, the major and minor semi-axes of the prolate ellipsoid formed by the complex, are determined from the solid-state structures.

coordination sphere completed by the $\mathrm{N}_{\text {amine }}$ atom and three $\mathrm{O}_{\text {ether }}$ atoms $(\mathrm{O}(14), \mathrm{O}(17)$ and $\mathrm{O}(23))$ from the aza-crown-ether fragment. The metal is located only $0.61 \AA$ above the mean plane constituted by these four heteroatoms, and taking the $\mathrm{O}_{\text {phenolate }}$ atom into account the geometry around $\mathrm{Li}(2)$ is intermediate between square pyramidal and trigonal bipyramidal $(\tau=$ $0.45) .{ }^{22}$ The remaining $\mathrm{O}_{\text {ether }}$ atom from the heterocyclic ring $(\mathrm{O}(11))$ binds to the second lithium atom, $\mathrm{Li}(1)$, which is only 3 -coordinate and sits on the other side of the aromatic ring with respect to $\operatorname{Li}(2)$. The geometry about $\operatorname{Li}(1)$ is trigonal planar, with the sum of the angles amounting to $359.72^{\circ}$. Note however that the distance to the $\mathrm{O}_{\text {ether }}$ atom from the crownether tether $(2.06 \AA)$ is much greater than that to the bridging $\mathrm{O}_{\text {phenolate }}$ atom $\left(\begin{array}{ll}1.83 & \AA\end{array}\right)$, and that significant deviations from the value of $120^{\circ}$ expected for perfectly trigonal planar geometries are observed around $\operatorname{Li}(1)$. The geometry around the $\mathrm{N}_{\text {amide }}$ atom is also trigonal planar; there is no evidence for $\mathrm{Li}(1) \cdots \mathrm{H}-\mathrm{Si}$ agostic interactions, as the $\mathrm{Si}(2)-\mathrm{N}(1)-\mathrm{Si}(1)$ angle of $129.2^{\circ}$ is unremarkable, the two $\operatorname{Li}(1) \cdots \mathrm{Si}(1)$ and $\mathrm{Li}(1) \cdots \operatorname{Si}(2)$ distances are commensurate $(2.99$ and $3.10 \AA$, respectively) and the two $\mathrm{Li}(1)-\mathrm{N}(1)-\mathrm{Si}(i)-\mathrm{H}$ cores deviate profoundly from coplanarity.

Due to its relevance for ensuing ROP investigations, the nuclearity of 1,2 and 4 in solution was assessed by pulsegradient spin-echo (PGSE) NMR spectroscopy, following protocols developed for related alkaline-earth complexes. ${ }^{9 j}$ All measurements were performed at $298 \mathrm{~K}$, using $7.0-10.0 \mathrm{mM}$ solutions. The translational motion of $\mathbf{1}$ was evaluated in dichloromethane- $\mathrm{d}_{2}$, whereas THF- $\mathrm{d}_{8}$ was employed for 2 and 4. The validity of our method was first assessed in both solvents using the archetypical $\mathrm{Si}\left(\mathrm{SiMe}_{3}\right)_{4}$ (TMSS) as a reference compound. From the PGSE experiments, the translational coefficient $D_{\mathrm{t}}$ was acquired for all compounds from the plot of $\ln \left(I / I_{0}\right)$ vs. $-\gamma^{2} \delta^{2} G^{2}(\Delta-\delta / 3) D_{\mathrm{t}}$ (see the Experimental section for details). The values of the hydrodynamic radius of the metal complex $\left(r_{\mathrm{H}, \mathrm{PGSE}}\right)$ thus determined are collected in Table $1 .^{23}$ Comparison of the hydrodynamic radii determined from its dimeric solid-state structure $\left(r_{\mathrm{H}, \mathrm{X} \text {-ray }}=7.10 \AA\right)$ and by PGSE experiments $\left(r_{\mathrm{H}, \mathrm{PGSE}}=3.15 \AA\right)$ demonstrates that $\mathbf{1}$ is monomeric in dichloromethane solutions; one can assume that upon splitting of the dimer in $\mathbf{1}$, the dangling chelating $\mathrm{O}_{\text {ether }}$ side-arm that did not interact with the metal in the solid state (vide supra) binds to the Li atom in solution to maintain the 4-coordinate nature of the metal centre. Similarly, the

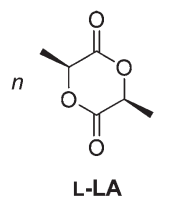

$n=50-100$

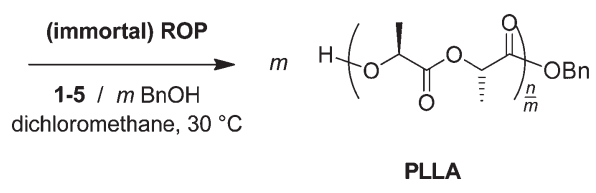

$m=1$ (ROP) or $2-4$ (iROP)
Scheme 1

solution hydrodynamic radii in THF- $\mathrm{d}_{8}$ for $\mathbf{2}$ and $\mathbf{4}$ determined by PGSE $\left(r_{\mathrm{H}, \mathrm{PGSE}}=4.84 \AA\right.$ and $4.98 \AA$ respectively $)$ are considerably smaller than those estimated crystallographically for $(2 \cdot \mathrm{THF})_{2}$ and $(4)_{2}\left(r_{\mathrm{H}, \mathrm{X} \text {-ray }}=7.55 \AA\right.$ and $7.88 \AA$ respectively), evidencing that these complexes are monomeric in THF. No information could be gained regarding their structures in aromatic hydrocarbons or chlorinated solvents owing to their limited solubility. As complex 3 was monomeric in the solidstate, we hypothesized that this would a fortiori be so in solution and under polymerisation conditions.

Note that DOSY NMR measurements performed on solutions of 5 in $\mathrm{C}_{6} \mathrm{D}_{6}(20.0 \mathrm{mM})$ at $298 \mathrm{~K}$ indicated that the complex retained its heteroleptic dinuclear structure in solution, as a single translational diffusion coefficient could be measured $\left(D_{\mathrm{t}}=7.57 \times 10^{-10} \mathrm{~m}^{2} \mathrm{~s}^{-1}\right) \cdot{ }^{24}$

\section{Ring-opening polymerisation studies}

The ability of complexes 1-4 (which are all monomeric under polymerisation conditions) and $\mathbf{5}$ to catalyze the living and immortal ROP of lactide upon addition of $\mathrm{BnOH}(0-4$ equiv.) was interrogated (Scheme 1). The reactions were typically carried out at $30^{\circ} \mathrm{C}$ in dichloromethane, ${ }^{25}$ using 50-100 equiv. of L-LA $v s$. the metal and $[\mathrm{L}-\mathrm{LA}]_{0}=0.5 \mathrm{M}$. The results of this qualitative screening are collected in Table 2.

Comparative experiments indicated that from all complexes tested in the presence of 1 equiv. of $\mathrm{BnOH}$, only $\left\{\mathrm{LO}^{3}\right\} \mathrm{Li}$ (3) afforded a suitable combination of catalytic activity and good control of the polymerisation parameters (Table 2, entries 1-5). Complexes 1 and 2 gave high reaction rates with nearcomplete monomer conversion in $2 \mathrm{~h}$, but at the expense of control over the polymerisation parameters as these were accompanied by broad molecular weight distributions (as a result of transesterification and/or poor initiation efficiency) for the resulting polymers $\left(M_{\mathrm{w}} / M_{\mathrm{n}}=1.76-1.87\right.$, entries 1 and 


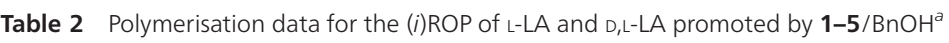

\begin{tabular}{|c|c|c|c|c|c|c|c|c|}
\hline Entry & Cat & {$[\mathrm{L}-\mathrm{LA}]_{0}:[\mathrm{Cat}]_{0}:[\mathrm{BnOH}]_{0}$} & Time $[\mathrm{h}]$ & Yield $^{b}[\%]$ & $M_{\mathrm{n}, \text { theo }}{ }^{c}\left[\mathrm{~g} \mathrm{~mol}^{-1}\right]$ & $M_{\mathrm{n}, \mathrm{SEC}}{ }^{d}\left[\mathrm{~g} \mathrm{~mol}^{-1}\right]$ & $M_{\mathrm{w}}{ }^{d} / M_{\mathrm{n}}$ & $M_{\mathrm{n}, \mathrm{NMR}}{ }^{e}\left[\mathrm{~g} \mathrm{~mol}^{-1}\right]$ \\
\hline 2 & 2 & $100: 1: 1$ & 2 & 87 & 12700 & 11100 & 1.76 & 11200 \\
\hline 4 & 4 & $100: 1: 1$ & 2 & 59 & 8600 & 10200 & 1.41 & 15000 \\
\hline 5 & 5 & $100: 1: 1$ & 2 & 86 & 12500 & 9800 & 1.63 & $\mathrm{n} / \mathrm{a}$ \\
\hline 6 & 3 & $100: 1: 0$ & 4 & 12 & 1700 & 8800 & 1.18 & $6500^{f}$ \\
\hline 7 & 3 & $50: 1: 1$ & 4 & 89 & 6500 & 7600 & 1.26 & 7400 \\
\hline 10 & 3 & $100: 1: 1$ & 4 & 70 & 10200 & 12500 & 1.17 & 14300 \\
\hline 11 & 3 & $100: 1: 1$ & 8 & 90 & 13100 & 16000 & 1.09 & 12500 \\
\hline 12 & 3 & $100: 1: 2$ & 8 & 92 & 6700 & 7400 & 1.28 & 7800 \\
\hline 13 & 3 & $100: 1: 4$ & 8 & 98 & 3700 & 4100 & 1.23 & 4200 \\
\hline $14^{g}$ & 3 & $100: 1: 1$ & 8 & 96 & 13800 & 12100 & 1.52 & 11500 \\
\hline
\end{tabular}

${ }^{a}$ Polymerisations in $\mathrm{CH}_{2} \mathrm{Cl}_{2}$ at $30{ }^{\circ} \mathrm{C}$ with $[\mathrm{L}-\mathrm{LA}]_{0}=0.5 \mathrm{M} .{ }^{b}$ Isolated yield after precipitation. ${ }^{c} M_{\mathrm{n}, \text { theo }}=[\mathrm{L}-\mathrm{LA}]_{\mathrm{o}} /[\mathrm{BnOH}]_{0} \times$ yield $\times 144.13+\mathrm{M} \mathrm{BnOH}$. ${ }^{d}$ Determined by size exclusion chromatography calibrated $v s$. polystyrene standards, and corrected by a factor of 0.58 according to literature recommendations. ${ }^{26}{ }^{e}$ Determined by end-group analysis. ${ }^{f}$ End-group analysis indicated the presence of $\mathrm{CH}\left(\mathrm{CH}_{3}\right) \mathrm{OH}$ and of the phenolate ligand as termini. ${ }^{g}$ ROP of D,L-LA; $P_{\mathrm{r}}=0.49$ (determined by homodecoupled ${ }^{1} \mathrm{H}$ NMR).

2). The two $\left\{\mathrm{LO}^{3}\right\} \mathrm{M}$ complexes $3(\mathrm{M}=\mathrm{Li})$ and $\mathbf{4}(\mathrm{M}=\mathrm{K})$ were equally fast (entries 3 and 4 ), but only the former yielded a narrowly dispersed PLLA $\left(M_{\mathrm{w}} / M_{\mathrm{n}}=1.05\right)$ and satisfactory agreement between theoretical and observed molecular weights. Prejudicial side-reactions with $\mathbf{4}$ such as epimerization of the chiral centres (as detected here to a sizeable extent by homodecoupled ${ }^{1} \mathrm{H}$ NMR spectroscopy) and transesterification reactions leading to a broad polydispersity index as observed $\left(M_{\mathrm{w}} / M_{\mathrm{n}}=1.41\right)$ can certainly be linked to the highly ionic nature of the $\mathrm{K}-\mathrm{O}_{\text {phenolate }}$ bond in this complex. The bimetallic complex $\mathbf{5}$ gave reaction rates comparable to those of $\mathbf{1}$ and $\mathbf{2}$, but the control over the ROP was also poor and, in addition, it proved impossible to determine molecular weight of the resulting PLLA by ${ }^{1} \mathrm{H}$ NMR, as no terminal group could be detected (entry 5); this last observation could tentatively be attributed to the presence of cyclic macromolecules, but our repeated attempts to record satisfactory MALDI-ToF MS data for this sample were uninformative. Except in the case of the erratic potassium initiator $\mathbf{4}$, good agreement was generally noticed between the values of $M_{\mathrm{n}}$ estimated by ${ }^{1} \mathrm{H}$ NMR and by size exclusion chromatography in the series of monometallic complexes 1-3.

Because 3 stood out by offering a suitable combination of reaction rates and control over the ROP parameters, its performance was further scrutinized (Table 2, entries 3 and 6-14). Without addition of exogenous alcohol (entry 6), the ROP of 100 equiv. of L-LA was slow and proceeded without adequate control; the initiation efficiency was indeed poor ( $c a$. 20\%), most probably a reflection of the poor nucleophilicity of (aminoether)phenolate moieties. End-group analysis of the resulting PLLA was consistent with initiation by acyl ringcleavage, resulting from nucleophilic attack of the phenolate ligand on the monomer; similar cases of initiation of the ROP process via insertion of the monomer in the lithiumphenolate bond have recently been documented for bimetallic amino-bisphenolate $\mathrm{Li}$ complexes. ${ }^{27}$ By contrast, upon

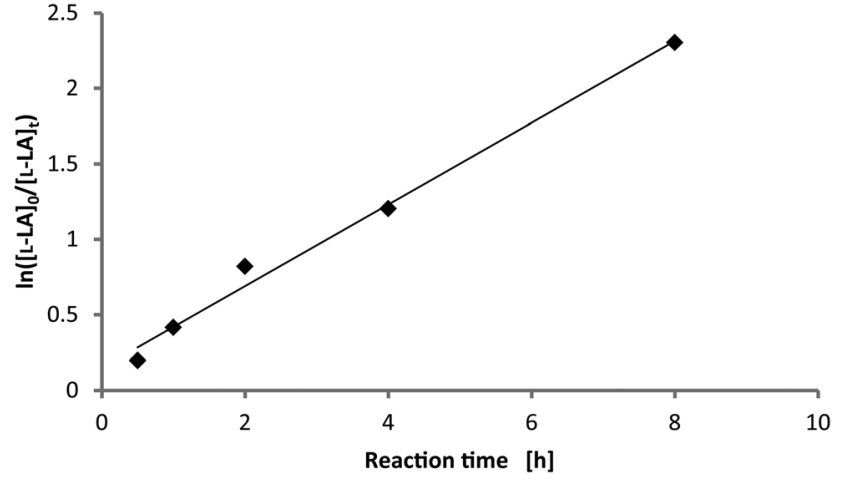

Fig. 7 Semi-logarithmic plot of monomer conversion vs. reaction time for the ROP of L-LA catalyzed by $3-\mathrm{BnOH}$. $[\mathrm{L}-\mathrm{LA}]_{0}=0.5 \mathrm{M}$ in dichloromethane, $[\mathrm{L}-\mathrm{LA}]_{0}-$ $[3]_{0}-[\mathrm{BnOH}]_{0}=100: 1: 1, T=30{ }^{\circ} \mathrm{C}$. Data points correspond to separate polymerisation runs in qualitative (Schlenk flask) experiments (Table 2, entries 3 and 8-11).

addition of 1 equiv. of $\mathrm{BnOH}$, the reaction rate was faster (compare entries 3 and 6) and the ROP took place with satisfactory control over the parameters, with values of $M_{\mathrm{w}} / M_{\mathrm{n}}$ typically in the range 1.05-1.30 depending on the reaction conditions. Under these conditions, conversion of the monomer follows first-order kinetics upon monomer concentration (Table 2, entries 3 and 8-11); in a first approximation, the value of $k_{\mathrm{obs}}=0.271(15) \mathrm{h}^{-1}$ was extracted for the observed rate constant from the linear $\left(R^{2}=0.9908\right)$ semi-logarithmic plot of monomer conversion $v s$. reaction time (Fig. 7). The molecular weight of the polymers increased regularly with monomer conversion while the distribution of the molecular weights remained narrow (Fig. 8; $1.05<M_{\mathrm{w}} / M_{\mathrm{n}}<1.17$ ). Besides, at equivalent monomer conversion and for constant alcohol contents, the molecular weight of the polymers doubled when the initial monomer loading was increased two-fold (entries 7 and 11). These observations suggest that the binary catalyst system 3-BnOH (in a 1:1 ratio) catalyses the living ROP of L-LA. The 


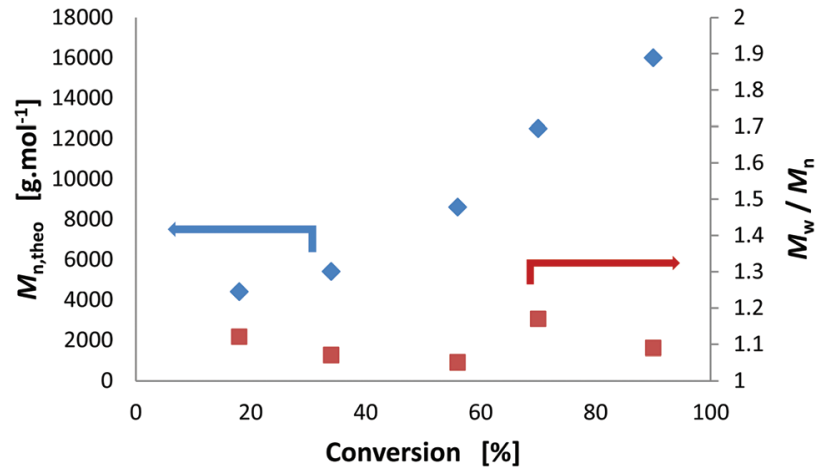

Fig. 8 Plot of molecular weight (blue, left $y$-axis) and molecular weight distribution (red, right $y$-axis) conversion vs. conversion for the ROP of L-LA catalyzed by $3-\mathrm{BnOH}$. $[\mathrm{L}-\mathrm{LA}]_{0}=0.5 \mathrm{M}$ in dichloromethane, $[\mathrm{L}-\mathrm{LA}]_{0}-[3]_{0}-[\mathrm{BnOH}]_{0}=$ $100: 1: 1, T=30^{\circ} \mathrm{C}$. Data points correspond to separate polymerisation runs in qualitative (Schlenk flask) experiments (Table 2, entries 3 and 8-11).

molecular weight of the polymers diminished proportionally when the contents in $\mathrm{BnOH}$ were increased (entries 11-13), which is diagnostic of a well-behaved immortal ROP with fast and reversible chain transfer between growing and dormant macroalcohols. ${ }^{15}$ This contrasts with previously reported piperazinyl-aminophenolate $\mathrm{Li}$ initiators for the living ROP of CL, which proved unable to catalyze immortal polymerisations. ${ }^{8 j}$ End-group fidelity in all cases was successfully established by a combination of MALDI-ToF MS and NMR $\left({ }^{1} \mathrm{H},{ }^{13} \mathrm{C}\left\{{ }^{1} \mathrm{H}\right\}\right.$ NMR) methods, which revealed that the two polymer chainends systematically and exclusively consisted of the expected $\mathrm{C}_{6} \mathrm{H}_{5} \mathrm{CH}_{2} \mathrm{O}-\mathrm{C}(=\mathrm{O})-\mathrm{CH}\left(\mathrm{CH}_{3}\right)-$ and $-\mathrm{CH}\left(\mathrm{CH}_{3}\right) \mathrm{OH}$ moieties (Scheme 1). The polymerisation of D,L-LA gave purely atactic polylactide, which exhibited a relatively broad molecular weight distribution (entry 14, $P_{\mathrm{r}}=0.49$ ).

In an attempt to get a more quantitative appreciation of the efficacy of the binary catalyst $3-\mathrm{BnOH}$, the conversion of 50 equiv. of L-LA vs. $3\left([\mathrm{~L}-\mathrm{LA}]_{0}-[3]_{0}-[\mathrm{BnOH}]_{0}=50: 1: 2\right)$ was monitored by ${ }^{1} \mathrm{H}$ NMR spectroscopy. ${ }^{28}$ First-order dependence upon monomer concentration was confirmed as the semilogarithmic plot of monomer conversion $v s$. reaction time was perfectly linear $\left(R^{2}=0.9974\right)$, and the corresponding observed rate constant was $k_{\mathrm{obs}}=0.0286(5) \mathrm{min}^{-1}$ (Fig. 9). This value of $k_{\mathrm{obs}}$ is logically larger than that measured earlier during qualitative Schlenk-scale reactions $\left(k_{\text {obs }}=0.271(15) \mathrm{h}^{-1}\right.$ or $\left.0.0045(2) \mathrm{min}^{-1}\right)$, on account of the higher concentrations in both 3 (2-fold increase) and $\mathrm{BnOH}$ (4-fold increase) employed in the present case. Relevant comparative data for other $\mathrm{Li}$ amino-bisphenolate catalyst systems for the ROP of L-LA are not available in the literature at the time of writing, ${ }^{8}$ but this value of $k_{\mathrm{obs}}$ is inferior to many of those reported for various group 2 and $12-14$ catalysts for the ROP of lactide..$^{3-6}$

The question of the associated operative mechanism in these and related alkali metal-based $\mathrm{ROH} /$ amino-bisphenolate ROP binary catalysts is of importance. When some ligandassisted mechanisms are sometimes proposed, they are ill-defined and have not been substantiated by concrete experimental back-up. ${ }^{8 b, f, g}$ In other cases, it is often stated that ROP

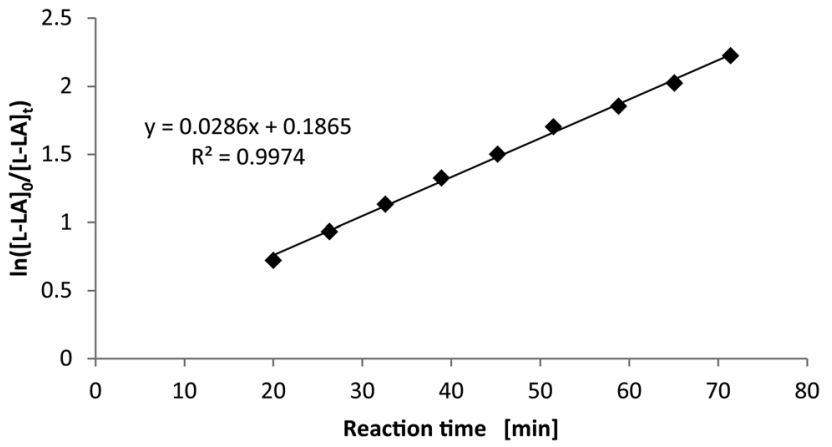

Fig. 9 Semi-logarithmic plot of monomer conversion vs. reaction time (conversion below 90\%) for the ROP of L-LA catalyzed by $3-\mathrm{BnOH}$ monitored by ${ }^{1} \mathrm{H}$ NMR spectroscopy. $T=30{ }^{\circ} \mathrm{C},[\mathrm{L}-\mathrm{LA}]_{0}=0.5 \mathrm{M}$ in dichloromethane- $\mathrm{d}_{2},[\mathrm{~L}-\mathrm{LA}]_{0}-$ $[3]_{0}-[\mathrm{BnOH}]_{0}=50: 1: 2$

catalyzed by such bi-component systems involve a coordination-insertion mechanism, ${ }^{29}$ but convincing experimental and/or theoretical evidence has not been provided to support this claim. In their investigation of Li-mediated ROP of CL, Kerton and co-workers proposed a scenario compatible with their observations that the nature of the substituents on the piperazinyl-aminophenolate influenced the rate of the reaction, an indication that the ligand therefore remained in the immediate vicinity of the metal during the whole catalytic process; yet, no definitive spectroscopic evidence was available.

Hence, stoichiometric and sub-catalytic reactions involving the three components of the ROP reaction ( $\mathrm{L}-\mathrm{LA}, 3$ and $\mathrm{BnOH}$ ) were investigated by ${ }^{1} \mathrm{H}$ NMR spectroscopy in dichloromethane- $\mathrm{d}_{2}$ at $303 \mathrm{~K}$, i.e. under conditions pertaining to those used for ROP catalysis (Fig. 10; see the Experimental section for details and the ESI $\dagger$ for the relevant ${ }^{1} \mathrm{H}$ NMR spectra). First, the evolution of a rigorously equimolar mixture of 3 and $\mathrm{BnOH}$ was monitored. Over the course of $45 \mathrm{~min}$, no sign of reaction was detected, and the ${ }^{1} \mathrm{H}$ NMR spectrum was the exact superimposition of the NMR spectra of 3 and $\mathrm{BnOH}$ taken separately under the same conditions; no release of $\left\{\mathrm{LO}^{3}\right\} \mathrm{H}$ nor formation of $\mathrm{BnOLi}$ were discerned, i.e. 3 proved to be perfectly stable. Note that in the presence of excess $\mathrm{BnOH}$ (5 equiv.), i.e. under conditions relevant to $i$ ROP catalysis, complex 3 also remained entirely unreacted. We checked that BnOLi is only sparingly soluble in dichloromethane- $\mathrm{d}_{2}$; yet, the equimolar reaction of freshly synthesized BnOLi and $\left\{\mathrm{LO}^{3}\right\} \mathrm{H}$ in this solvent at $303 \mathrm{~K}$ led as anticipated to immediate and quantitative formation of a clear solution of 3 and $\mathrm{BnOH}$ as revealed within the first point of ${ }^{1} \mathrm{H}$ NMR analysis.

Next, the reaction of a $1: 1: 1$ mixture of $3, \mathrm{BnOH}$ and L-LA was monitored under the same conditions. We found that the product of ring-opening insertion of BnOH into L-LA, benzyl-2((2-hydroxypropanoyl)oxy)propanoate $\left(\mathbf{P}_{\mathbf{1}}\right)$, had formed quantitatively within the first point of analysis. On the other hand, 3 was left intact (no formation of free or coordinated $\left\{\mathrm{LO}^{3}\right\} \mathrm{H}$ was visible, and the presence of BnOLi could not be detected at 


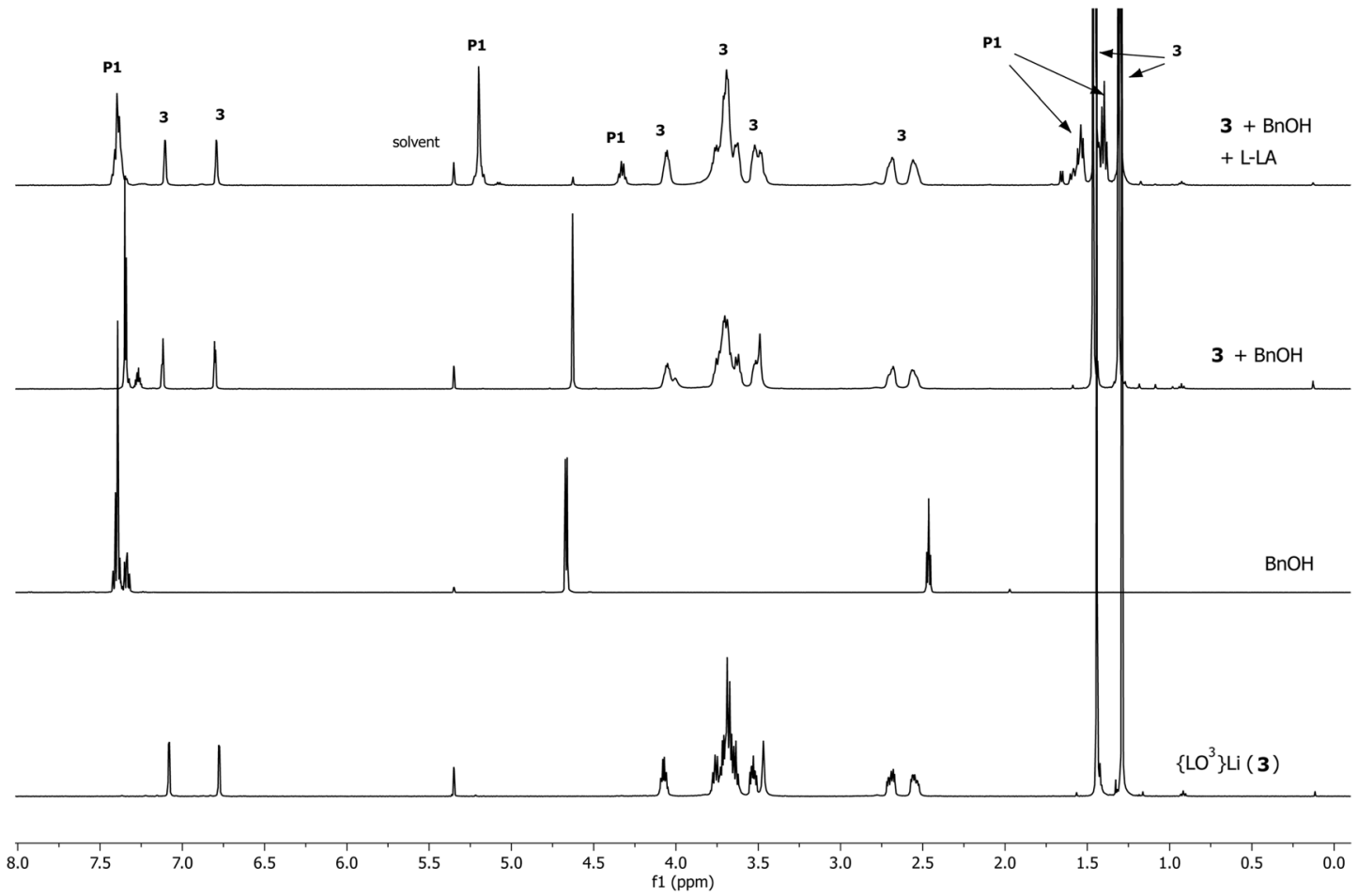

Fig. 10 Monitoring of stoichiometric (i.e. $1: 1$ or $1: 1: 1)$ model reactions by ${ }^{1} \mathrm{H}$ NMR in dicholoromethane- $\mathrm{d}_{2}$ at $303 \mathrm{~K}(500.13 \mathrm{MHz})$. $\mathbf{P}_{\mathbf{1}}$ and $\mathbf{3}$ stand for benzyl-2((2-hydroxypropanoyl)oxy)propanoate and $\left\{L^{3}\right\} L i$, respectively.

any stage of the reaction), and negligible amounts of unreacted $\mathrm{BnOH}$ and L-LA persisted. After an additional $60 \mathrm{~min}$ at $303 \mathrm{~K}$, no evolution of the system was observed other than complete consumption of the monomer and $\mathrm{BnOH}$. In addition, we made the same observations and therefore drew identical conclusions during the monitoring of the reaction of a 1:5:5 mixture of 3, $\mathrm{BnOH}$ and L-LA, i.e. under experimental conditions corresponding to the initial stage of $i$ ROP reactions.

Finally, we also followed spectroscopically the reaction of a $1: 1: 2$ mixture of $3, \mathrm{BnOH}$ and L-LA. The reaction was slow (full completion required several hours at $303 \mathrm{~K}$ ), but the recorded ${ }^{1} \mathrm{H}$ NMR data were fully consistent with selective production of $\mathrm{BnO}\left[\mathrm{C}(=\mathrm{O}) \mathrm{CH}\left(\mathrm{CH}_{3}\right) \mathrm{O}\right]_{3} \mathrm{C}(=\mathrm{O}) \mathrm{CH}\left(\mathrm{CH}_{3}\right) \mathrm{OH}\left(\mathbf{P}_{2}\right)$, i.e. the product of double ring-opening ensuing from nucleophilic attack by $\mathrm{BnOH}$ and following $\mathbf{P}_{\mathbf{1}}$.

On the basis of these findings combined with end-group analyses (MALDI-ToF MS, ${ }^{1} \mathrm{H}$ NMR) of the PLLAs obtained during catalyzed (i)ROP reactions, we propose that ROP mediated by $3-\mathrm{BnOH}$, be it simply living or living immortal upon addition of 1 or 5 equiv. of $\mathrm{BnOH} v s$. 3 respectively, proceeds via an activated monomer mechanism such as that outlined in Scheme 2, and not according to a coordinationinsertion one as frequently assumed. This ligandassisted (through activation of the exogenous nucleophile via $\mathrm{O}_{\text {phenolate }} \cdots \mathrm{H}$ hydrogen bonding) mechanism is reminiscent of that we recently suggested for $i$ ROP reactions mediated by

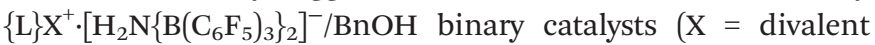
alkaline- or rare-earth metal). ${ }^{30}$

\section{Conclusion}

We have prepared several lithium and potassium aminoetherphenolate complexes. These have all been structurally characterized, illustrating a broad range of coordination motifs in the solid state, varying with the chelating ability of the ancillary ligand, size of the metal and even number of metallic centres found in the different complexes. PGSE NMR studies have shown that even if some of these complexes are dimeric in the solid state, they are monomeric in solution which renders them easily implementable as catalysts in the ROP of L-LA.

ROP investigations have been carried out under very mild conditions, and have revealed that in the presence of exogenous alcohol, the lithium complexes generally enabled well-controlled, albeit slow, reactions. In particular, we have found that the most electron-rich and hindered $\left\{\mathrm{LO}^{3}\right\} \mathrm{Li}$ complex allows for excellent control of the ROP parameters, and is suitable for both the living and living immortal ROP of L-LA. The specific electron-donating and chelating nature of the $\left\{\mathrm{LO}^{3}\right\}^{-}$ligand has allowed to improve significantly the reactivity of Li-aminoether-phenolate complexes, as by comparison $\mathrm{Li}$ complexes incorporating the less stabilizing $\left\{\mathrm{LO}^{1}\right\}^{-}$and $\left\{\mathrm{LO}^{2}\right\}^{-}$gave less controllable reactions. The combination of polymer end-group analyses and stoichiometric model reactions monitored by ${ }^{1} \mathrm{H}$ NMR has allowed us to demonstrate for the first time that living as well as living immortal ROP reactions catalyzed by these binary $\left\{\mathrm{LO}^{i}\right\} \mathrm{Li}-\mathrm{BnOH}$ systems follow an activated monomer mechanism, and not the coordination-insertion 
<smiles>CC(C)(C)c1cc(CN2CCOCCOCCOCC2[O-])c(OC(=O)[O-])c(C(C)(C)C)c1</smiles>

$\left\{\mathrm{LO}^{3}\right\} \mathrm{Li}(3)$

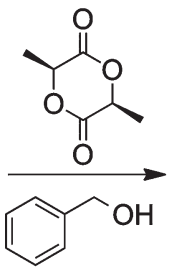

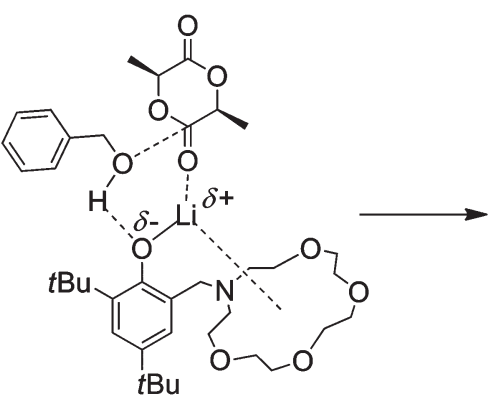

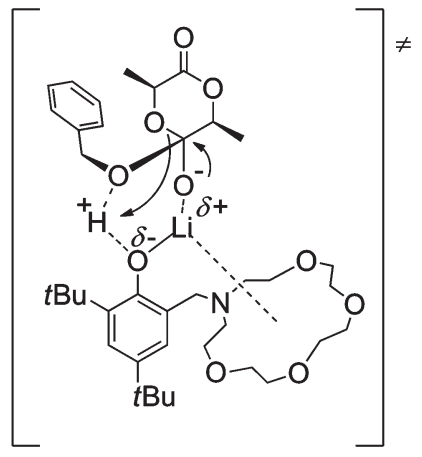<smiles>[3H][V]</smiles><smiles>C[C@H](O)C(=O)O[C@@H](C)C(=O)OCc1ccccc1</smiles>

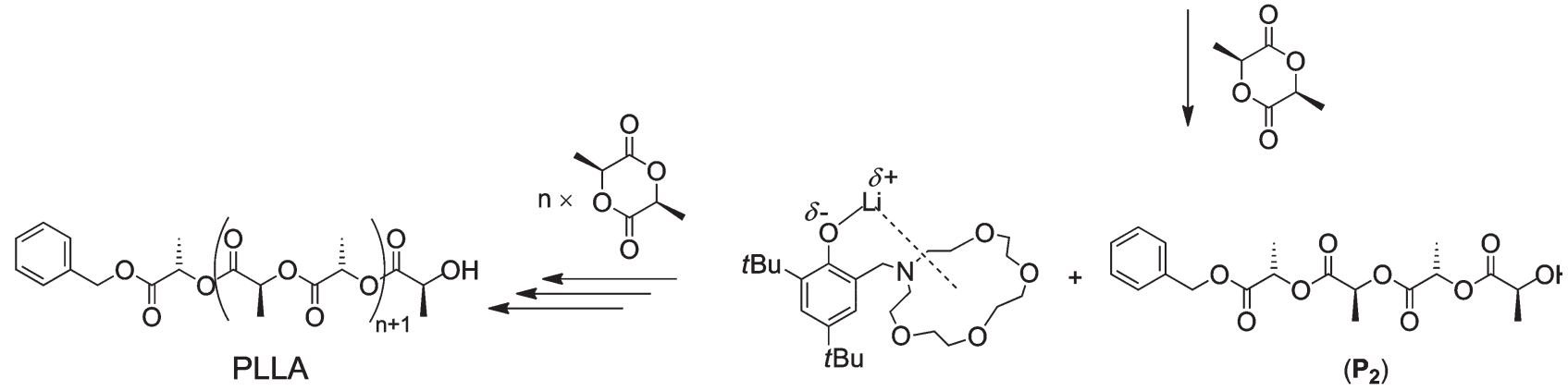

Scheme 2 Proposed activated monomer mechanism for the (i)ROP of L-LA mediated by $3-\mathrm{BnOH}$.

scenario commonly claimed for related phenolate-alcohol systems. It is unclear at this stage whether this conclusion can be extended to other alkaline catalysts where alternative pathways have been evoked, ${ }^{8}$ as it may be that the nature of the operative mechanism depends on the relative basicity of the phenolate which varies with the identity of the chelating side-arm (aza-15-c-5 as in 3, morpholine as in 2, piperazine $^{8 j} \ldots$ ); yet, it suggests that a reappraisal of the relevant operative mechanisms may indeed be possible under the light of this new experimental evidence.

\section{Experimental section}

\section{General procedures}

All manipulations were performed under an inert atmosphere using standard Schlenk techniques or in a dry, solvent-free glove-box (Jacomex; $\mathrm{O}_{2}<1$ ppm, $\mathrm{H}_{2} \mathrm{O}<5 \mathrm{ppm}$ ) for catalyst loading. $\mathrm{HN}\left(\mathrm{SiMe}_{2} \mathrm{H}\right)(\mathrm{ABCR})$ was dried over $3 \AA$ activated molecular sieves and distilled prior to use. Benzyl alcohol was dried and distilled over magnesium turnings and stored over $3 \AA$ molecular sieves. The pro-ligands $\left\{\mathrm{LO}^{1}\right\} \mathrm{H},\left\{\mathrm{LO}^{2}\right\} \mathrm{H}$ and $\left\{\mathrm{LO}^{3}\right\} \mathrm{H}$ were prepared as described in the literature. ${ }^{16,19}$ Solvents (THF, $\mathrm{Et}_{2} \mathrm{O}, \mathrm{CH}_{2} \mathrm{Cl}_{2}$, pentane and toluene) were purified and dried (water contents all below $6 \mathrm{ppm}$ ) over alumina columns (MBraun SPS). THF was further distilled under argon from sodium mirror/benzophenone ketyl prior to use. All deuterated solvents (Eurisotop, Saclay, France) were stored in sealed ampoules over activated $3 \AA$ molecular sieves and were thoroughly degassed by several freeze-thaw-vacuum cycles. Technical grade L-LA was provided by Total Petrochemicals and purified by recrystallization from a hot $\left(80^{\circ} \mathrm{C}\right)$, concentrated iPrOH solution, followed by two subsequent recrystallizations in hot $\left(105{ }^{\circ} \mathrm{C}\right)$ toluene. After purification, L-LA was stored at all times at $-30{ }^{\circ} \mathrm{C}$ under the inert atmosphere of the glovebox. D,L-LA (Acros) was purified in the same way.

NMR spectra were recorded on Bruker AC-300, AM-400 and AM-500 spectrometers. All ${ }^{1} \mathrm{H}$ and ${ }^{13} \mathrm{C}\left\{{ }^{1} \mathrm{H}\right\}$ chemicals shifts 
were determined using residual signals of the deuterated solvents and were calibrated $v s$. $\mathrm{SiMe}_{4}$. Assignment of the signals was carried out using $1 \mathrm{D}\left({ }^{1} \mathrm{H},{ }^{13} \mathrm{C}\left\{{ }^{1} \mathrm{H}\right\}\right)$ and 2D (COSY, HMBC, HMQC) NMR experiments. Coupling constants are given in Hertz. A capillary containing an aqueous solution of $\mathrm{LiCl}\left(\delta_{\mathrm{Li}}=\right.$ 0 ppm) was used for the calibration of ${ }^{7} \mathrm{Li}$ NMR spectra. $\left\{{ }^{1} \mathrm{H}{ }^{29}\right.$ Si NMR spectra were referenced using a capillary containing $\mathrm{SiMe}_{4}\left(\delta_{\mathrm{Si}}=0 \mathrm{ppm}\right)$.

PGSE NMR experiments were carried out on a Bruker Avance III $400 \mathrm{MHz}$ spectrometer equipped with a BBOF pulsed field-gradient probe using a bipolar gradient pulse stimulated echo sequence. Each experiment was performed on a $0.1 \mathrm{M}$ solution at $298 \mathrm{~K}$ using a spectral width of $4807 \mathrm{~Hz}$, a $90^{\circ}$ pulse width of $11.5 \mu \mathrm{s}$, a diffusion delay time of $0.05 \mathrm{~s}$, and a total diffusion-encoding pulse width of $0.0016 \mathrm{~s}$. The diffusion encoding pulse strength was arrayed from 0 to $35 \mathrm{G}$ $\mathrm{cm}^{-2}$ over 12 or 16 increments with four dummy scans and 8 scans per increment. The translational coefficient $D_{\mathrm{t}}$ was acquired for all compounds from the plot of $\ln \left(I / I_{0}\right) v s$. $-\gamma^{2} \delta^{2} G^{2}(\Delta-\delta / 3) D_{\mathrm{t}}$, where $I$ is the amplitude of the spin-echoed signal, $I_{0}$ is the intensity without gradient, $\gamma$ is the gyromagnetic ratio, $\delta$ is the duration of the gradient pulse, $G$ is the strength of the gradient and $\Delta$ is the diffusion time; ${ }^{31} \delta, G$ and $\Delta$ are set experimental parameters. For each complex, the correction factor $f_{\mathrm{s}}^{\text {met }}$ was determined crystallographically according to eqn (1), where $a$ and $b$ are respectively the main and minor semi-axes of the prolate ellipsoid formed by the complex. $^{32}$ From the Stoke-Einstein equation (eqn (2), where $k_{\mathrm{B}}$ is the Boltzmann constant, $T$ is the temperature and $\eta$ is the fluid viscosity), the product $c^{\text {met }} \times r_{\mathrm{H}}^{\text {met }}$ (where $c^{\text {met }}$ and $r_{\mathrm{H}}^{\text {met }}$ are the correction factor and the hydrodynamic radius of the metal complex respectively) can be calculated according to eqn (3). The values of $r_{\mathrm{H}}^{\mathrm{met}}$ were then deduced empirically by plotting $c^{\text {met }} \times r_{\mathrm{H}}^{\text {met }}$ according to Chen's equation (eqn (4)), ${ }^{33}$ using $r_{\mathrm{H}}^{\text {solv }}=2.46 \AA$ for dichloromethane- $\mathrm{d}_{2}$ and $2.79 \AA$ for $\mathrm{THF}-\mathrm{d}_{8} \cdot{ }^{34}$

$$
\begin{gathered}
f_{\mathrm{s}}^{\text {met }}=\frac{\sqrt{1-\left(\frac{b}{a}\right)^{2}}}{\left(\frac{b}{a}\right)^{2 / 3} \ln \frac{1+\sqrt{1-\left(\frac{b}{a}\right)^{2}}}{\left(\frac{b}{a}\right)}} \\
c^{\text {met }} r_{\mathrm{H}}^{\text {met }}=\frac{D_{\mathrm{t}}^{\mathrm{TMSS}} c^{\mathrm{TMSS}} f_{\mathrm{s}}^{\mathrm{TMSS}} r_{\mathrm{H}}^{\mathrm{TMSS}}}{D_{\mathrm{t}}^{\mathrm{met}} f_{\mathrm{s}}^{\mathrm{met}}} \\
c^{\mathrm{met}} r_{\mathrm{H}}^{\mathrm{met}}=\frac{k_{\mathrm{B}} T}{6 r_{\mathrm{H}}^{\mathrm{met}}} \\
1+0.695\left(\frac{r_{\mathrm{H}}^{\mathrm{solv}}}{r_{\mathrm{H}}^{\mathrm{met}}}\right)^{2.234}
\end{gathered}
$$

Elemental analyses were performed on a Carlo Erba 1108 Elemental Analyzer instrument at the London Metropolitan
University by Stephen Boyer and were the average of a minimum of two independent measurements.

FTIR spectra were recorded as nujoll mulls in $\mathrm{KBr}$ plates on a Shimadzu AffinitIR instrument.

Size Exclusion Chromatography (SEC) measurements were performed on a Polymer Laboratories PL-GPC 50 instrument equipped with two PLgel $5 \AA$ MIXED-C columns and a refractive index detector. The column was eluted with THF at room temperature at $1.0 \mathrm{~mL} \min ^{-1}$ and was calibrated using 11 monodisperse polystyrene standards in the range of 580 to $380000 \mathrm{~g} \mathrm{~mol}^{-1}$. According to literature recommendations, ${ }^{26}$ the molecular weights of all PLAs were corrected by a factor of 0.58 .

\section{$\left\{\mathrm{LO}^{1}\right\} \mathrm{Li}(1)$}

$n$ BuLi (0.75 mL of $1.6 \mathrm{M}$ solution in hexanes, $1.20 \mathrm{mmol}$ ) in $\mathrm{Et}_{2} \mathrm{O}(5 \mathrm{~mL})$ was added to a solution of $\left\{\mathrm{LO}^{1}\right\} \mathrm{H}(470 \mathrm{mg}$, $1.33 \mathrm{mmol})$ in $\mathrm{Et}_{2} \mathrm{O}(10 \mathrm{~mL})$. The reaction mixture was stirred overnight at room temperature. Removal of the volatiles under vacuum yielded a colourless solid which was washed with pentane $(3 \times 5 \mathrm{~mL})$ and taken to dryness to give $\left\{\mathrm{LO}^{1}\right\} \mathrm{Li}(\mathbf{1})$ as a white powder $(210 \mathrm{mg}, 50 \%)$. Single crystals of $(\mathbf{1})_{2}$ suitable for X-ray diffraction were obtained from a cold pentane- $\mathrm{Et}_{2} \mathrm{O}$ mixture. ${ }^{1} \mathrm{H}$ NMR (400.13 MHz, $298 \mathrm{~K}$, benzene- $\left.\mathrm{d}_{6}\right): \delta_{\mathrm{H}} 7.58(\mathrm{~d}$, ${ }^{4} J_{\mathrm{HH}}=2.5 \mathrm{~Hz}, 1 \mathrm{H}$, arom- $\left.H\right), 7.09\left(\mathrm{~d},{ }^{4} J_{\mathrm{HH}}=2.5 \mathrm{~Hz}, 1 \mathrm{H}\right.$, arom$H$ ), 3.27 (overlapping br s, $2 \mathrm{H}, \mathrm{ArCH}_{2} \mathrm{~N}$ ), 3.21 (br m, 4H, $\mathrm{OCH}_{2}$ ), 3.01 (br m, 4H, $\mathrm{NCH}_{2} \mathrm{CH}_{2}$ ), 2.92 (br s, 6H, OCH $), 1.73$ (s, 9H, o-C(CH $\left.)_{3}\right), 1.46\left(\mathrm{~s}, 9 \mathrm{H}, p-\mathrm{C}\left(\mathrm{CH}_{3}\right)_{3}\right) \mathrm{ppm} .{ }^{13} \mathrm{C}\left\{{ }^{1} \mathrm{H}\right\} \mathrm{NMR}$ (100.62 MHz, $298 \mathrm{~K}$, benzene- $\mathrm{d}_{6}$ ): $\delta_{\mathrm{C}} 165.04$ (i-C), $136.53(o-\mathrm{C})$, 133.26 ( $p$-C), 126.64 (m-C), 125.56 (o-C), 123.67 (m-C), 70.50 $\left(\mathrm{OCH}_{2}\right), 63.20\left(\mathrm{ArCH}_{2} \mathrm{~N}\right), 58.68\left(\mathrm{OCH}_{3}\right), 58.46\left(\mathrm{NCH}_{2} \mathrm{CH}_{2}\right)$, $35.62\left(o-C\left(\mathrm{CH}_{3}\right)_{3}\right), 34.10\left(p-C\left(\mathrm{CH}_{3}\right)_{3}\right), 32.47\left(p-\mathrm{C}\left(\mathrm{CH}_{3}\right)_{3}\right), 30.44$ $\left(o-\mathrm{C}\left(\mathrm{CH}_{3}\right)_{3}\right)$ ppm. ${ }^{7} \mathrm{Li}$ NMR (155.51 MHz, $298 \mathrm{~K}$, benzene-d $\left.\mathrm{d}_{6}\right)$ : $\delta_{\mathrm{Li}} 0.99 \mathrm{ppm}$. Found $\mathrm{C} 70.4, \mathrm{H} 10.5, \mathrm{~N} 4.1 \% . \mathrm{C}_{21} \mathrm{H}_{36} \mathrm{LiNO}_{3}$ (357.46 $\mathrm{g} \mathrm{mol}^{-1}$ ) requires C 70.6, H 10.1, N 3.9\%.

\section{$\left\{\mathrm{LO}^{2}\right\} \mathbf{L i}(2)$}

Following the same procedure as that described for $\mathbf{1},\left\{\mathrm{LO}^{2}\right\} \mathrm{Li}$ (2) was isolated as a white solid (350 $\mathrm{mg}, 60 \%)$ by reaction of $\left\{\mathrm{LO}^{2}\right\} \mathrm{H}(570 \mathrm{mg}, 1.86 \mathrm{mmol})$ and $n \mathrm{BuLi}(1.2 \mathrm{~mL}$ of $1.6 \mathrm{M}$ solution in hexanes, $1.92 \mathrm{mmol}) .{ }^{1} \mathrm{H}$ NMR $(500.13 \mathrm{MHz}, 298 \mathrm{~K}$, THF-d ${ }_{8}$ ): $\delta_{\mathrm{H}} 7.12$ (br s, $1 \mathrm{H}$, arom- $H$ ), 6.81 (br s, $1 \mathrm{H}$, arom- $H$ ), 3.8-3.3 (br m, 6H, $\mathrm{OCH}_{2}+\mathrm{ArCH}_{2} \mathrm{~N}$ ), 2.49 (br s, $4 \mathrm{H}, \mathrm{NCH}_{2} \mathrm{CH}_{2}$ ), $1.46\left(\mathrm{~s}, 9 \mathrm{H}, o-\left(\mathrm{CH}_{3}\right)_{3}\right), 1.24\left(\mathrm{~s}, 9 \mathrm{H}, p-\left(\mathrm{CH}_{3}\right)_{3}\right) \mathrm{ppm} .{ }^{13} \mathrm{C}\left\{{ }^{1} \mathrm{H}\right\} \mathrm{NMR}$ (125.76 MHz, $298 \mathrm{~K}$, THF-d ${ }_{8}$ ): $\delta_{\mathrm{C}} 167.00$ (i-C), $137.14(m-\mathrm{C})$, 133.76 ( $p$-C), 128.40 ( $m$-C), 124.88 (o-C), 124.74 (o-C), 67.29 $\left(\mathrm{OCH}_{2}\right), 64.83\left(\mathrm{ArCH}_{2} \mathrm{~N}\right), 55.92\left(\mathrm{NCH}_{2} \mathrm{CH}_{2}\right), 36.88\left(o-C\left(\mathrm{CH}_{3}\right)_{3}\right)$, $35.14\left(p-C\left(\mathrm{CH}_{3}\right)_{3}\right), 33.31\left(p-\mathrm{C}\left(\mathrm{CH}_{3}\right)_{3}\right), 32.07\left(o-\mathrm{C}\left(\mathrm{CH}_{3}\right)_{3}\right)$ ppm. ${ }^{7} \mathrm{Li}$ NMR (155.51 MHz, $\left.298 \mathrm{~K}, \mathrm{THF}_{8}\right): \delta_{\mathrm{Li}} 0.86 \mathrm{ppm}$. Found: $\mathrm{C} 73.3, \mathrm{H}$ 9.7, $\mathrm{N}$ 4.4\%. $\mathrm{C}_{19} \mathrm{H}_{30} \mathrm{LiN}_{1} \mathrm{O}_{2}\left(311.39 \mathrm{~g} \mathrm{~mol}^{-1}\right)$ requires: C 73.3, H 9.7, N 4.5\%. X-ray quality crystals of $\left(\left\{\mathrm{LO}^{2}\right\} \mathrm{Li} \cdot \mathrm{THF}\right)_{2}$ $\left((2 \cdot \mathbf{T H F})_{2}\right)$ were obtained by recrystallization from a THFpentane mixture stored at $-26{ }^{\circ} \mathrm{C}$. 


\section{$\left\{\mathrm{LO}^{3}\right\} \mathbf{L i}(3)$}

$n$ BuLi (10.0 mL of 1.6 M solution in hexanes, $16.0 \mathrm{mmol}$ ) was added in portions to a solution of $\left\{\mathrm{LO}^{3}\right\} \mathrm{H}(7.2 \mathrm{~g}, 16.5 \mathrm{mmol})$ in $\mathrm{Et}_{2} \mathrm{O}(100 \mathrm{~mL})$. The resulting solution was stirred for $1 \mathrm{~h}$, warmed up slowly to room temperature, and volatiles were removed in vacuo. The resulting powder was washed with cold pentane $(3 \times 25 \mathrm{~mL})$ to remove the excess of the pro-ligand, affording the pure salt as a colourless powder after drying to constant weight $(6.95 \mathrm{~g}, 95 \%)$. Single-crystals of 3 suitable for $\mathrm{X}$-ray diffraction studies were grown from a concentrated $\mathrm{Et}_{2} \mathrm{O}$ solution at $+2{ }^{\circ} \mathrm{C} .{ }^{1} \mathrm{H}$ NMR $\left(500.13 \mathrm{MHz}, 298 \mathrm{~K}\right.$, benzene- $\left.\mathrm{d}_{6}\right)$ : $\delta_{\mathrm{H}} 7.68\left(\mathrm{~d},{ }^{4} J_{\mathrm{HH}}=2.8 \mathrm{~Hz}, 1 \mathrm{H}, \operatorname{arom}-H\right), 7.16\left(\mathrm{~d},{ }^{4} J_{\mathrm{HH}}=2.8 \mathrm{~Hz}\right.$, $1 \mathrm{H}$, arom- $H$ ), $3.79\left(\mathrm{~m}, 2 \mathrm{H}, \mathrm{OCH}_{2}\right), 3.50\left(\mathrm{~s}, 2 \mathrm{H}, \mathrm{ArCH}_{2} \mathrm{~N}\right), 3.37$ $\left(\mathrm{m}, 2 \mathrm{H}, \mathrm{OCH}_{2}\right), 3.23\left(\mathrm{~m}, 2 \mathrm{H}, \mathrm{OCH}_{2}\right), 3.15\left(\mathrm{~m}, 2 \mathrm{H}, \mathrm{OCH}_{2}\right), 3.05$ $\left(\mathrm{m}, 4 \mathrm{H}, \mathrm{OCH}_{2}\right), 2.97\left(\mathrm{~m}, 2 \mathrm{H}, \mathrm{OCH}_{2}\right), 2.90\left(\mathrm{~m}, 2 \mathrm{H}, \mathrm{OCH}_{2}\right), 2.44$ $(\mathrm{m}, 1 \mathrm{H}+1 \mathrm{H}, \mathrm{N}(\mathrm{CHH})(\mathrm{CHH})), 2.12(\mathrm{~m}, 1 \mathrm{H}+1 \mathrm{H}, \mathrm{N}(\mathrm{CH} H)$ $(\mathrm{CH} H)), 1.94$ (s, 9H, o-C(CH$\left.)_{3}\right), 1.59\left(\mathrm{~s}, 9 \mathrm{H}, p-\mathrm{C}-\left(\mathrm{CH}_{3}\right)_{3}\right) \mathrm{ppm}$. ${ }^{13} \mathrm{C}\left\{{ }^{1} \mathrm{H}\right\}$ NMR (125.76 MHz, $298 \mathrm{~K}$, benzene- $\left.\mathrm{d}_{6}\right): \delta_{\mathrm{C}} 168.21(\mathrm{i}-\mathrm{C})$, $136.41(\mathrm{o}-\mathrm{C}), 129.18(\mathrm{o}-\mathrm{C}), 125.99(\mathrm{~m}-\mathrm{C}), 123.20$ and $123.18(\mathrm{~m}-$ $\mathrm{C}$ and $p$-C), $69.21\left(\mathrm{OCH}_{2}\right), 68.93\left(\mathrm{OCH}_{2}\right), 68.76\left(\mathrm{OCH}_{2}\right), 67.24$ $\left(\mathrm{OCH}_{2}\right), 59.34\left(\mathrm{ArCH}_{2} \mathrm{~N}\right), 52.71\left(\mathrm{NCH}_{2} \mathrm{CH}_{2}\right), 35.93\left(o-C\left(\mathrm{CH}_{3}\right)_{3}\right)$, $34.18\left(p-C\left(\mathrm{CH}_{3}\right)_{3}\right), 32.88\left(p-\mathrm{C}\left(\mathrm{CH}_{3}\right)_{3}\right), 30.45\left(o-\mathrm{C}\left(\mathrm{CH}_{3}\right)_{3}\right)$ ppm. ${ }^{7} \mathrm{Li}$ NMR (155.51 MHz, $298 \mathrm{~K}$, benzene-d $\left.{ }_{6}\right): \delta_{\mathrm{Li}} 0.07 \mathrm{ppm}$. Found C 67.6, H 9.7, N 3.3\%. $\mathrm{C}_{25} \mathrm{H}_{42} \mathrm{LiNO}_{5}\left(443.55 \mathrm{~g} \mathrm{~mol}^{-1}\right.$ ) requires $\mathrm{C} 67.7, \mathrm{H} 9.5, \mathrm{~N} 3.2 \%$.

\section{$\left\{\mathrm{LO}^{3}\right\} \mathrm{K}(4)$}

$\mathrm{KH}(640 \mathrm{mg}, 16.0 \mathrm{mmol})$ was added in portions with a bent finger to a solution of $\left\{\mathrm{LO}^{3}\right\} \mathrm{H}(7.2 \mathrm{~g}, 16.5 \mathrm{mmol})$ in THF $(100 \mathrm{~mL})$. The resulting solution was stirred for $1 \mathrm{~h}$, warmed to room temperature before volatiles were pulled off in vacuo. The resulting powder was washed with pentane $(3 \times 25 \mathrm{~mL})$ to yield 4 as a white powder $(7.0 \mathrm{~g}, 92 \%)$. Single crystals of $(\mathbf{4})_{2}$ suitable for X-ray diffraction were obtained from a saturated $\mathrm{Et}_{2} \mathrm{O}$ solution at room temperature. ${ }^{1} \mathrm{H}$ NMR $(400.13 \mathrm{MHz}, 298 \mathrm{~K}$, THF-d $): \delta_{\mathrm{H}} 7.01\left(\mathrm{~d},{ }^{4} J_{\mathrm{HH}}=2.8 \mathrm{~Hz}, 1 \mathrm{H}, \operatorname{arom}-H\right), 6.76\left(\mathrm{~d},{ }^{4} J_{\mathrm{HH}}=\right.$ $2.8 \mathrm{~Hz}, 1 \mathrm{H}$, arom- $\mathrm{H}), 3.70-2.35\left(\mathrm{~m}, 22 \mathrm{H}\right.$, all $\mathrm{OCH}_{2}$ and $\left.\mathrm{NCH}_{2}\right)$, 1.49 (s, 9H, o-C $\left.\left(\mathrm{CH}_{3}\right)_{3}\right), 1.27\left(\mathrm{~s}, 9 \mathrm{H}, p-\mathrm{C}\left(\mathrm{CH}_{3}\right)_{3}\right) \mathrm{ppm} .{ }^{13} \mathrm{C}\left\{{ }^{1} \mathrm{H}\right\}$ NMR (100.62 MHz, $298 \mathrm{~K}$, THF-d $\left.{ }_{8}\right): \delta_{\mathrm{C}} 170.38$ (i-C), 136.69 (o-C), 127.80 (m-C), 127.12 ( $p$-C), 125.55 (o-C), $123.34(m-\mathrm{C})$, 71.06, 70.98, 70.58, $69.55\left(\right.$ all $\left.\mathrm{CH}_{2} \mathrm{O}\right), 65.48\left(\mathrm{ArCH}_{2} \mathrm{~N}\right), 57.52$ $\left(\mathrm{NCH}_{2} \mathrm{CH}_{2}\right), 36.85\left(o-C\left(\mathrm{CH}_{3}\right)_{3}\right), 34.99\left(p-C\left(\mathrm{CH}_{3}\right)_{3}\right), 33.68(p-\mathrm{C}-$ $\left.\left(\mathrm{CH}_{3}\right)_{3}\right), 31.50\left(o_{-} \mathrm{C}\left(\mathrm{CH}_{3}\right)_{3}\right)$ ppm. Found: $\mathrm{C} 62.9, \mathrm{H} 8.9, \mathrm{~N} 2.8 \%$. $\mathrm{C}_{25} \mathrm{H}_{42} \mathrm{KNO}_{5}\left(475.70 \mathrm{~g} \mathrm{~mol}^{-1}\right.$ ) requires: $\mathrm{C} 63.1, \mathrm{H}$ 8.9, $\mathrm{N} 2.9 \%$.

\section{$\left\{\mathrm{LO}^{3}\right\} \operatorname{Li} \cdot \operatorname{LiN}\left(\mathrm{SiMe}_{2} \mathrm{H}\right)_{2}(5)$}

A solution of $\left\{\mathrm{LO}^{3}\right\} \mathrm{H}(420 \mathrm{mg}, 0.60 \mathrm{mmol})$ in $\mathrm{Et}_{2} \mathrm{O}(10 \mathrm{~mL})$ was added dropwise to a solution of $\mathrm{LiN}\left(\mathrm{SiMe}_{2} \mathrm{H}\right)_{2}(278 \mathrm{mg}$, $2.00 \mathrm{mmol})$ in $\mathrm{Et}_{2} \mathrm{O}(10 \mathrm{~mL})$, and the resulting solution was stirred overnight at room temperature. It was then concentrated to a saturated solution and pentane (ca. $4 \mathrm{~mL}$ ) was used to precipitate the final product. The supernatant was filtered off and the isolated solid was thoroughly washed with pentane $(4 \times 15 \mathrm{~mL})$ and dried in vacuo to give 5 as a white powder (395 mg, 70\%). X-ray quality crystals of 5 were grown at room temperature from a 1:5 mixture of $\mathrm{Et}_{2} \mathrm{O}$ and pentane. ${ }^{1} \mathrm{H}$ NMR (400.13 MHz, $233 \mathrm{~K}$, toluene-d ${ }_{8}$ ): $\delta_{\mathrm{H}} 7.49$ (br s, $1 \mathrm{H}$, arom- $H$ ), 7.02 (br s, $1 \mathrm{H}$, arom- $H$ ), $5.31\left(\mathrm{~m}, 2 \mathrm{H},{ }^{1} J_{\mathrm{SiH}}=166.5 \mathrm{~Hz}, \mathrm{Si} H\right)$, $4.53(\mathrm{~m}, 1 \mathrm{H}, \operatorname{ArCHHN}), 4.01\left(\mathrm{~m}, 2 \mathrm{H}, \mathrm{OCH}_{2}\right), 3.88(\mathrm{~m}, 1 \mathrm{H}$, $\mathrm{OCH}), 3.65(\mathrm{~m}, 1 \mathrm{H}, \mathrm{OCH}), 3.10-2.50(\mathrm{~m}, 13 \mathrm{H}, \operatorname{ArCH} H \mathrm{~N}$ and $\left.\mathrm{OCH}_{2}\right), 2.26\left(\mathrm{~m}, 2 \mathrm{H}, \mathrm{NCH}_{2} \mathrm{CH}_{2}\right), 1.96\left(\mathrm{~m}, 1 \mathrm{H}, \mathrm{NCHHCH}_{2}\right)$, $1.68\left(\mathrm{~s}, 9 \mathrm{H}, \mathrm{p}-\mathrm{C}\left(\mathrm{CH}_{3}\right)_{3}\right), 1.59\left(\mathrm{~m}, 1 \mathrm{H}, \mathrm{NCHHCH}_{2}\right), 1.45(\mathrm{~s}, 9 \mathrm{H}$, $\left.o-\mathrm{C}\left(\mathrm{CH}_{3}\right)_{3}\right), 0.49$ (br s, 6H, $\mathrm{SiCH}_{3}$ ), 0.37 (br s, 6H, $\mathrm{SiCH}_{3}$ ) ppm. ${ }^{13} \mathrm{C}\left\{{ }^{1} \mathrm{H}\right\}$ NMR (100.62 MHz, $233 \mathrm{~K}$, toluene-d $\left.{ }_{8}\right): \delta_{\mathrm{C}} 163.84(\mathrm{i}-\mathrm{C})$, 136.47 (o-C), 133.42 (p-C), 126.16 ( $m$-C), 124.95 (o-C), 123.38 (m-C), 68.23, 67.88, 67.80, 67.56, 67.06, 66.90, 65.82, 65.30 (all $\left.\mathrm{OCH}_{2}\right), 58.50\left(\mathrm{ArCH}_{2} \mathrm{~N}\right), 53.79$ and 51.91 (both $\mathrm{NCH}_{2} \mathrm{CH}_{2}$ ), $35.22\left(o-C\left(\mathrm{CH}_{3}\right)_{3}\right), 34.08\left(p-C\left(\mathrm{CH}_{3}\right)_{3}\right), 32.40\left(p-\mathrm{C}\left(\mathrm{CH}_{3}\right)_{3}\right), 31.13$ $\left(o-\mathrm{C}\left(\mathrm{CH}_{3}\right)_{3}\right), 5.97$ and 5.81 (both $\mathrm{SiCH}_{3}$ ) ppm. ${ }^{7} \mathrm{Li} \mathrm{NMR}$ $\left(155.51 \mathrm{MHz}, 298 \mathrm{~K}\right.$, benzene-d ${ }_{6}$ ): $\delta_{\mathrm{Li}} 1.14 \quad$ (ArO $\cdots L i \mathrm{~N}-$ $\left.\left(\mathrm{SiMe}_{2} \mathrm{H}\right)_{2}\right),-0.46\left(\operatorname{ArOLi} \cdots \mathrm{N}\left(\mathrm{SiMe}_{2} \mathrm{H}\right)_{2}\right)$ ppm. $\left\{{ }^{1} \mathrm{H}\right\}^{29} \mathrm{Si}$ NMR $\left(79.49 \mathrm{MHz}, 298 \mathrm{~K}\right.$, benzene- $\mathrm{d}_{6}$ ): $\delta_{\mathrm{Si}}-27.9 \mathrm{ppm}$. FTIR (Nujol in KBr plates): $\nu=1992$ (s), 1773 (m), 1602 (m), 1461 (s), 1455 (s), 1414 (s), 1376 (s), 1321 (s), 1302 (s), 1109 (s), 887 (s), 825 (s) $\mathrm{cm}^{-1}$. Found: C 59.8, H 9.7, N 4.8\%. $\mathrm{C}_{29} \mathrm{H}_{56} \mathrm{Li}_{2} \mathrm{~N}_{2} \mathrm{O}_{5} \mathrm{Si}_{2}$ $\left(582.82 \mathrm{~g} \mathrm{~mol}^{-1}\right)$ requires: C 59.2, $\mathrm{H} \mathrm{9.4,} \mathrm{N} 4.7 \%$.

\section{${ }^{1} \mathrm{H}$ NMR monitoring of stoichiometric reactions}

The ${ }^{1} \mathrm{H}$ NMR spectra (500.13 MHz) of $\left\{\mathrm{LO}^{3}\right\} \mathrm{H}, 3$, BnOH, BnOLi, L-LA, a 1:1 mixture of BnOH-3 (42.6 $\mathrm{mol}$ of each), and a $1: 1: 1$ mixture of $\mathrm{BnOH}-3-\mathrm{L}-\mathrm{LA}(44.4 \mu \mathrm{mol}$ of each) were recorded at $303 \mathrm{~K}$ in dichloromethane-d $\mathrm{d}_{2}\left(0.65 \mathrm{~mL} ; \delta_{\mathrm{H}}\right.$ $5.35 \mathrm{ppm})$.

For BnOH, $\delta_{\mathrm{H}} 7.42-7.32\left(\mathrm{~m}, 5 \mathrm{H}, \mathrm{C}_{6} H_{5}\right), 4.67\left(\mathrm{~d},{ }^{3} J_{\mathrm{HH}}=\right.$ $\left.6.0 \mathrm{~Hz}, 2 \mathrm{H}, \mathrm{C}_{6} \mathrm{H}_{5} \mathrm{CH}_{2} \mathrm{OH}\right), 2.46\left(\mathrm{t},{ }^{3} J_{\mathrm{HH}}=6.0 \mathrm{~Hz}, 1 \mathrm{H}\right.$, $\left.\mathrm{C}_{6} \mathrm{H}_{5} \mathrm{CH}_{2} \mathrm{OH}\right)$ ppm.

For L-LA, $\delta_{\mathrm{H}} 5.08\left(\mathrm{q},{ }^{3} J_{\mathrm{HH}}=6.5 \mathrm{~Hz}, 2 \mathrm{H}, \mathrm{OCHCH}_{3}\right), 1.65(\mathrm{~d}$, $\left.{ }^{3} J_{\mathrm{HH}}=6.5 \mathrm{~Hz}, 6 \mathrm{H}, \mathrm{OCHCH}_{3}\right) \mathrm{ppm}$.

For $\left\{\mathrm{LO}^{3}\right\} \mathrm{H}, \delta_{\mathrm{H}} 10.72$ (br s, $1 \mathrm{H}$, aryl-OH), $7.22(\mathrm{~s}, 1 \mathrm{H}$, arom$H), 6.87\left(\mathrm{~s}, 1 \mathrm{H}\right.$, arom- $H$ ), $3.78\left(\mathrm{~s}, 2 \mathrm{H}, \mathrm{ArCH}_{2} \mathrm{~N}\right), 3.70-3.61(\mathrm{~m}$, $16 \mathrm{H}$, all $\left.\mathrm{OCH}_{2}\right), 2.78\left(\mathrm{t},{ }^{3} \mathrm{~J}_{\mathrm{HH}}=5.5 \mathrm{~Hz}, 4 \mathrm{H}, \mathrm{NCH}_{2} \mathrm{CH}_{2}\right), 1.44(\mathrm{~s}$, 9H, $\left.\mathrm{C}\left(\mathrm{CH}_{3}\right)_{3}\right), 1.30\left(\mathrm{~s}, 9 \mathrm{H}, \mathrm{C}\left(\mathrm{CH}_{3}\right)_{3}\right) \mathrm{ppm}$.

For BnOLi (the acquisition of rigorously accurate data was precluded by the very poor solubility of the title compound in dichloromethane- $\left.\mathrm{d}_{2}\right), \delta_{\mathrm{H}} 7.37-7.13(\mathrm{~m}, 3 \mathrm{H}$, meta and para arom- $H), 7.04\left(\mathrm{~d},{ }^{3} J_{\mathrm{HH}}=6.0 \mathrm{~Hz}, 2 \mathrm{H}\right.$, ortho arom- $H$ ), 4.48 (br s, $\left.2 \mathrm{H}, \mathrm{C}_{6} \mathrm{H}_{5} \mathrm{CH}_{2} \mathrm{OLi}\right) \mathrm{ppm}$.

For 3, $\delta_{\mathrm{H}} 7.08\left(\mathrm{~d}, 1 \mathrm{H},{ }^{4} J_{\mathrm{HH}}=2.8 \mathrm{~Hz}\right.$, arom- $\left.H\right), 6.78(\mathrm{~d}, 1 \mathrm{H}$, ${ }^{4} J_{\mathrm{HH}}=2.8 \mathrm{~Hz}$, arom- $\left.H\right), 4.07(\mathrm{~m}, 2 \mathrm{H}), 3.76-3.64(\mathrm{~m}, 12 \mathrm{H}), 3.53$ (m, 2H), 3.47 (br s, 2H), 2.69 (m, 2H), 2.55 (m, 2H), 1.44 (s, 9H, $\left.\mathrm{C}\left(\mathrm{CH}_{3}\right)_{3}\right), 1.29\left(\mathrm{~s}, 9 \mathrm{H}, \mathrm{C}\left(\mathrm{CH}_{3}\right)_{3}\right)$.

For the 1:1 mixture of $\mathrm{BnOH}$ and 3, no sign that a reaction took place was detected: $\delta_{\mathrm{H}} 7.47-7.25\left(\mathrm{~m}, 5 \mathrm{H}, \mathrm{C}_{6} \mathrm{H}_{5} \mathrm{CH}_{2} \mathrm{OH}\right)$, $7.12\left(\mathrm{~d},{ }^{4} J_{\mathrm{HH}}=2.8 \mathrm{~Hz}, 1 \mathrm{H}\right.$, arom- $H$ from 3), $6.80\left(\mathrm{~d},{ }^{4} J_{\mathrm{HH}}=2.8\right.$ $\mathrm{Hz}, 1 \mathrm{H}$, arom- $H$ from 3), 4.63 (br s, 2H, $\mathrm{C}_{6} \mathrm{H}_{5} \mathrm{CH}_{2} \mathrm{OH}$ ), 4.07-4.00 (m, 2H from 3), 3.75-3.61 ( $\mathrm{m}, 12 \mathrm{H}$ from 3 ), 3.52-3.47 (m, $4 \mathrm{H}$ from 3), 2.69 ( $\mathrm{m}, 2 \mathrm{H}$ from 3), 2.55 (m, 2H from 3), 1.46 $\left(\mathrm{s}, 9 \mathrm{H}, \mathrm{C}\left(\mathrm{CH}_{3}\right)_{3}\right.$ from 3), $1.31\left(\mathrm{~s}, 9 \mathrm{H}, \mathrm{C}\left(\mathrm{CH}_{3}\right)_{3}\right.$ from 3$) \mathrm{ppm}$.

For the 5:1 mixture of $\mathrm{BnOH}$ and 3, chemical shifts essentially identical to those seen in the $1: 1$ reaction above were detected. 
Table 3 Summary of crystallographic data for complexes $(\mathbf{1})_{2},(\mathbf{2} \cdot \mathbf{T H F})_{2}, \mathbf{3},(\mathbf{4})_{2}$ and $\mathbf{5}$

\begin{tabular}{|c|c|c|c|c|c|}
\hline & $(\mathbf{1})_{2}$ & $(2 \cdot \mathbf{T H F})_{2}$ & 3 & $(4)_{2}$ & 5 \\
\hline $\begin{array}{l}\text { Empirical formula } \\
\text { CCDC number }\end{array}$ & $\begin{array}{l}\mathrm{C}_{42} \mathrm{H}_{72} \mathrm{Li}_{2} \mathrm{~N}_{2} \mathrm{O}_{6} \\
885948\end{array}$ & $\begin{array}{l}\mathrm{C}_{46} \mathrm{H}_{76} \mathrm{Li}_{2} \mathrm{~N}_{2} \mathrm{O}_{6} \\
885949\end{array}$ & $\begin{array}{l}\mathrm{C}_{25} \mathrm{H}_{42} \mathrm{LiNO}_{5} \\
885950\end{array}$ & $\begin{array}{l}\mathrm{C}_{50} \mathrm{H}_{84} \mathrm{~K}_{2} \mathrm{~N}_{2} \mathrm{O}_{10} \\
905220\end{array}$ & $\begin{array}{l}\mathrm{C}_{29} \mathrm{H}_{56} \mathrm{Li}_{2} \mathrm{~N}_{2} \mathrm{O}_{5} \mathrm{Si}_{2} \\
905352\end{array}$ \\
\hline Crystal system & Monoclinic & Triclinic & Monoclinic & Monoclinic & Monoclinic \\
\hline Space group & $C 2 / c$ & $P \overline{1}$ & $P 21 / n$ & $P 21 / n$ & $P 21 / n$ \\
\hline$a(\AA)$ & $26.792(9)$ & $10.740(3)$ & $15.9897(10)$ & $17.3807(5)$ & $10.0152(3)$ \\
\hline$b(\AA)$ & $8.593(3)$ & $11.668(3)$ & $9.9413(7)$ & $17.0158(5)$ & $22.0468(6) \mathrm{A}$ \\
\hline$\beta\left({ }^{\circ}\right)$ & 99.763(19) & $100.525(12)$ & $95.297(4)$ & $111.7240(10)$ & $98.016(2)$ \\
\hline$\gamma\left({ }^{\circ}\right)$ & 90 & $95.069(13)$ & 90 & 90 & 90 \\
\hline Volume $\left(\AA^{3}\right)$ & 4381(3) & $2297.6(11)$ & $2580.7(3)$ & $5515.5(3)$ & $3538.65(18)$ \\
\hline$Z$ & 4 & 2 & 4 & 4 & 4 \\
\hline Density $\left(\mathrm{g} \mathrm{cm}^{-3}\right)$ & 1.084 & 1.109 & 1.142 & 1.146 & 1.094 \\
\hline Abs. coeff. $\left(\mathrm{mm}^{-1}\right)$ & 0.070 & 0.071 & 0.077 & 0.224 & 0.135 \\
\hline & $-25<l<24$ & $-24<l<28$ & $-21<l<18$ & $-23<l<26$ & $-20<l<20$ \\
\hline$R_{\text {int }}$ & 0.0687 & 0.0556 & 0.0465 & 0.0433 & 0.0244 \\
\hline Reflec. collected & 17316 & 28356 & 20944 & 46530 & 23321 \\
\hline Reflec. unique $[I>2 \sigma(I)]$ & 4946 & 10200 & 5845 & 12537 & 8033 \\
\hline Data/restraints/param. & $4946 / 0 / 243$ & $10200 / 0 / 523$ & $5845 / 0 / 295$ & $12537 / 6 / 590$ & $8033 / 0 / 381$ \\
\hline Goodness-of-fit on $F^{2}$ & 0.966 & 1.022 & 1.099 & 1.019 & 1.033 \\
\hline$R_{1}[I>2 \sigma(I)]$ (all data) & $0.0825(0.1347)$ & $0.0600(0.1245)$ & $0.0431(0.0594)$ & $0.0427(0.0943)$ & $0.0397(0.0498)$ \\
\hline $\mathrm{w} R_{2}[I>2 \sigma(I)]$ (all data) & $0.2290(0.2802)$ & $0.1356(0.167)$ & $0.1209(0.1379)$ & $0.0729(0.107)$ & $0.1026(0.1095)$ \\
\hline Largest diff. e $\mathrm{A}^{-3}$ & 0.615 and -0.456 & 0.371 and -0.442 & 0.320 and -0.330 & 0.458 and -0.295 & 0.383 and -0.362 \\
\hline
\end{tabular}

For the $1: 1: 1$ mixture of $\mathrm{BnOH}, \mathrm{L}-\mathrm{LA}$ and 3 leading to the formation of benzyl-2-((2-hydroxypropanoyl)oxy)propanoate $\left(\mathbf{P}_{1}\right)$ together with 1 equiv. of unmodified 3: $\delta_{\mathrm{H}} 7.47-7.32(\mathrm{~m}$, $5 \mathrm{H}, \mathrm{C}_{6} H_{5}$ from $\left.\mathbf{P}_{\mathbf{1}}\right), 7.10\left(\mathrm{~d},{ }^{4} J_{\mathrm{HH}}=2.8 \mathrm{~Hz}, 1 \mathrm{H}\right.$, arom $-H$ from 3 ), $6.79\left(\mathrm{~d},{ }^{4} J_{\mathrm{HH}}=2.8 \mathrm{~Hz}, 1 \mathrm{H}\right.$, arom- $H$ from 3), 5.22-5.16 (overlapping bs s and q, $3 \mathrm{H}, \mathrm{C}_{6} \mathrm{H}_{5} \mathrm{CH}_{2} \mathrm{OC}(\mathrm{O}) \mathrm{CH}\left(\mathrm{CH}_{3}\right)$ from $\left.\mathbf{P}_{\mathbf{1}}\right), 4.32$ $\left(\mathrm{q},{ }^{3} \mathrm{~J}_{\mathrm{HH}}=6.5 \mathrm{~Hz}, 1 \mathrm{H}, \mathrm{CH}\left(\mathrm{CH}_{3}\right) \mathrm{OH}\right.$ from $\left.\mathbf{P}_{\mathbf{1}}\right), 4.09-4.02(\mathrm{~m}, 2 \mathrm{H}$ from 3), 3.80-3.58 (m, $12 \mathrm{H}$ from 3$)$, 3.54-3.44 (m, $4 \mathrm{H}$ from 3$)$, $2.68(\mathrm{~m}, 2 \mathrm{H}$ from 3$), 2.56(\mathrm{~m}, 2 \mathrm{H}$ from 3$), 1.54(\mathrm{~m}, 3 \mathrm{H}$, BnOC$(\mathrm{O}) \mathrm{CH}\left(\mathrm{CH}_{3}\right)$ from $\left.\mathbf{P}_{\mathbf{1}}\right), 1.45\left(\mathrm{~s}, 9 \mathrm{H}, \mathrm{C}\left(\mathrm{CH}_{3}\right)_{3}\right.$ from 3), 1.42 (q, ${ }^{3} J_{\mathrm{HH}}=6.5 \mathrm{~Hz}, 3 \mathrm{H}, \mathrm{CH}\left(\mathrm{CH}_{3}\right) \mathrm{OH}$ from $\left.\mathbf{P}_{\mathbf{1}}\right), 1.31\left(\mathrm{~s}, 9 \mathrm{H}, \mathrm{C}\left(\mathrm{CH}_{3}\right)_{3}\right.$ from 3) ppm.

For the $5: 5: 1$ mixture of $\mathrm{BnOH}, \mathrm{L}-\mathrm{LA}$ and 3 , chemical shifts essentially identical to those seen in the $1: 1: 1$ reaction above were detected.

\section{Typical polymerisation procedure}

All manipulations were performed under an inert atmosphere. In the glove-box, the metal-based precursor (typically 5 to $20 \mathrm{mg}$ ) and the purified monomer ( $c a .0 .2$ to $5.0 \mathrm{~g}$ ) were placed at once in a large Schlenk flask. The vessel was sealed and removed from the glove-box. All subsequent operations were carried out using standard Schlenk techniques. Where needed, the required amount of dry, degassed solvent selected from dichloromethane or toluene was added with a syringe to the Schlenk flask containing the precursor and monomer. The metallic complex was then activated by addition of pure $\mathrm{BnOH}$. The alcohol was added rapidly, the Schlenk vessel was immersed in an oil bath pre-set at the desired temperature and the polymerisation time was measured from this point. The reaction was terminated by addition of acidified $\mathrm{MeOH}$ $(\mathrm{HCl} 1 \% ; 1.0 \mathrm{~mL})$ and the polymer was precipitated in methanol (100 mL). It was purified by re-precipitation, using dichloromethane or THF as a solvent and methanol as a non-solvent. The polymer was then dried to constant weight under dynamic vacuum.

\section{Crystal structure determination}

Suitable crystals for X-ray diffraction analysis of $(\mathbf{1})_{2},(\mathbf{2} \cdot \mathbf{T H F})_{2}$, $3,(4)_{2}$ and 5 were obtained by recrystallization of the purified products. Diffraction data were collected at $150 \mathrm{~K}$ using a Bruker APEX CCD diffractometer with graphite-monochromated MoK $\alpha$ radiation $(\lambda=0.71073 \AA)$. A combination of $\omega$ and $\Phi$ scans was carried out to obtain at least a unique data set. The crystal structures were solved by direct methods, remaining atoms were located from difference Fourier synthesis followed by full-matrix least-squares refinement based on F2 (programs SIR97 and SHELXL-97). ${ }^{35}$ Many hydrogen atoms could be found from the Fourier difference analysis. Carbonand oxygen-bound hydrogen atoms were placed at calculated positions and forced to ride on the attached atom. The hydrogen atom contributions were calculated but not refined. All non-hydrogen atoms were refined with anisotropic displacement parameters. The locations of the largest peaks in the final difference Fourier map calculation as well as the magnitude of the residual electron densities were of no chemical significance. Relevant collection and refinement data are summarized in Table 3. 


\section{Acknowledgements}

The authors are grateful to the Agence Nationale de la Recherche (grant ANR-11-BS07-009-01 to SCR) and CNRS for financial support. We thank Total Petrochemicals for the generous gift of L-lactide, Stephen Boyer (London Metropolitan University) for running combustion analyses and Jean-Paul Guégan (ENSC Rennes) for his assistance with PGSE NMR measurements.

\section{Notes and references}

1 R. E. Drumright, P. R. Gruber and D. E. Henton, Adv. Mater., 2000, 12, 1841.

2 For organocatalysts, see: (a) N. E. Kamber, W. Jeong, R. M. Waymouth, R. C. Pratt, B. G. G. Lohmeijer and J. L. Hedrick, Chem. Rev., 2007, 107, 5813; (b) M. K. Kiesewetter, E. J. Shin, J. L. Hedrick and R. M. Waymouth, Macromolecules, 2010, 43, 2093.

3 For leading reviews, see: (a) B. J. O'Keefe, M. A. Hillmyer and W. B. Tolman, J. Chem. Soc., Dalton Trans., 2001, 2215; (b) O. Dechy-Cabaret, B. Martin-Vaca and D. Bourissou, Chem. Rev., 2004, 104, 6147; (c) C. A. Wheaton, P. G. Hayes and B. J. Ireland, Dalton Trans., 2009, 4832; (d) C. M. Thomas, Chem. Soc. Rev., 2010, 39, 165; (e) M. J. Stanford and A. P. Dove, Chem. Soc. Rev., 2010, 39, 486.

4 For leading $\mathrm{Al}$ references, see: (a) N. Spassky, M. Wisniewski, C. Pluta and A. Le Borgne, Macromol. Chem. Phys., 1996, 197, 2627; (b) T. M. Ovitt and G. W. Coates, J. Am. Chem. Soc., 1999, 121, 4072; (c) T. M. Ovitt and G. W. Coates, J. Am. Chem. Soc., 2002, 124, 1316; (d) N. Nomura, R. Ishii, M. Akakura and K. Aoi, J. Am. Chem. Soc., 2002, 124, 5938; (e) P. Hormnirun, E. L. Marshall, V. C. Gibson, A. J. P. White and D. J. Williams, J. Am. Chem. Soc., 2004, 126, 2688; (f) N. Nomura, R. Ishii, Y. Yamamoto and T. Kondo, Chem.-Eur. J., 2007, 13, 4433; $(g)$ H. Du, A. H. Velders, P. J. Dijkstra, J. Sun, Z. Zhong, X. Chen and J. Feijen, Chem.-Eur. J., 2009, 15, 9836; (h) N. Nomura, A. Akita, R. Ishii and M. Mizuno, J. Am. Chem. Soc., 2010, 132, 1750; (i) R. O. MacRae, C. M. Pask, L. K. Burdsall, R. S. Blackburn, C. M. Rayner and P. C. McGowan, Angew. Chem., Int. Ed., 2011, 50, 291; (j) E. L. Whitelaw, G. Loraine, M. F. Mahon and M. D. Jones, Dalton Trans., 2011, 40, 11469; (k) P. J. Dijkstra, H. Du and J. Feijen, Polym. Chem., 2011, 2, 520; (l) W. Zhao, Y. Wang, X. Liu, X. Chen, D. Cui and E. Y.-X. Chen, Chem. Commun., 2012, 48, 6375.

5 For leading $\mathrm{Zn}$ references, see: (a) M. Cheng, A. B. Attygalle, E. B. Lobkovsky and G. W. Coates, J. Am. Chem. Soc., 1999, 121, 11583; (b) B. M. Chamberlain, M. Cheng, D. R. Moore, T. M. Ovitt, E. B. Lobkovsky and G. W. Coates, J. Am. Chem. Soc., 2001, 123, 3229; (c) C. K. Williams, L. E. Breyfogle, S. K. Choi, W. Nam, V. G. Young Jr., M. A. Hillmyer and W. B. Tolman, J. Am. Chem. Soc., 2003, 125, 11350; (d) V. Poirier, T. Roisnel,
J.-F. Carpentier and Y. Sarazin, Dalton Trans., 2009, 9820; (e) J. Börner, U. Flörke, K. Huber, A. Döring, D. Kuckling and S. Herres-Pawlis, Chem.-Eur. J., 2009, 15, 2362; (f) D. J. Darensbourg and O. Karroonnirun, Inorg. Chem., 2010, 49, 2360; $(g)$ C. A. Wheaton and P. G. Hayes, Chem. Commun., 2010, 46, 8404; (h) J. Börner, I. dos Santos Vieira, A. Pawlis, A. Döring, D. Kuckling and S. Herres-Pawlis, Chem.-Eur. J., 2011, 17, 4507; (i) E. Piedra-Arroni, P. Brignou, A. Amgoune, S. M. Guillaume, J.-F. Carpentier and D. Bourissou, Chem. Commun., 2011, 47, 9828; (j) P. Brignou, S. M. Guillaume, T. Roisnel, D. Bourissou and J.-F. Carpentier, Chem.-Eur. J., 2012, 18, 9360.

6 For leading references with rare-earth metals, see ref. $4 a, b$ and: (a) B. M. Chamberlain, B. A. Jazdzewski, M. Pink, M. A. Hillmyer and W. B. Tolman, Macromolecules, 2000, 33, 3970; (b) L. R. Rieth, D. R. Moore, E. B. Lobkovsky and G. W. Coates, J. Am. Chem. Soc., 2002, 124, 15239; (c) C.-X. Cai, A. Amgoune, C. W. Lehmann and J.-F. Carpentier, Chem. Commun., 2004, 330; (d) A. Amgoune, C. M. Thomas, T. Roisnel and J.-F. Carpentier, Chem.-Eur. J., 2006, 12, 169; (e) A. Amgoune, C. M. Thomas, S. Ilinca, T. Roisnel and J.-F. Carpentier, Angew. Chem., Int. Ed., 2006, 45, 2782; (f) H. Ma, T. P. Spaniol and J. Okuda, Angew. Chem., Int. Ed., 2006, 45, 7818; (g) H. E. Dyer, S. Huijser, A. D. Schwarz, C. Wang, R. Duchateau and P. Mountford, Dalton Trans., 2008, 32; $(h)$ A. Otero, J. Fernández-Baeza, A. Lara-Sánchez, C. Alonso-Moreno, I. Márquez-Segovia, L. F. Sánchez-Barba and A. M. Rodríguez, Angew. Chem., Int. Ed., 2009, 48, 2176; (i) H. E. Dyer, S. Huijser, N. Susperregui, F. Bonnet, A. D. Schwarz, R. Duchateau, L. Maron and P. Mountford, Organometallics, 2010, 29, 3602; $(j)$ J. W. Kramer, D. S. Treitler, E. W. Dunn, P. M. Castro, T. Roisnel, C. M. Thomas and G. W. Coates, J. Am. Chem. Soc., 2009, 131, 16042; (k) L. Clark, M. G. Cushion, H. E. Dyer, A. D. Schwarz, R. Duchateau and P. Mountford, Chem. Commun., 2010, 46, 273; (l) Z. Zhang and D. Cui, Chem.-Eur. J., 2011, 17, 11520.

7 (a) G. Rokicki, Prog. Polym. Sci., 2000, 25, 259; (b) A.-C. Albertsson and I. K. Varma, Biomacromolecules, 2003, 4, 1466; (c) M. Vert, Biomacromolecules, 2005, 6, 538; (d) S. Matsumura, Adv. Polym. Sci., 2005, 194, 95; (e) A. Corma, S. Iborra and A. Velty, Chem. Rev., 2007, 107, 2411; $(f)$ B. D. Ulery, L. S. Nair and C. T. Laurencin, J. Polym. Sci., Part B: Polym. Phys., 2011, 49, 832; (g) F. Suriano, O. Coulembier, J. L. Hedrick and P. Dubois, Polym. Chem., 2011, 2, 528.

8 For a recent review on Li ROP initiators, see: (a) A. Kumar Sutar, T. Maharana, S. Dutta, C.-T. Chen and C.-C. Lin, Chem. Soc. Rev., 2010, 39, 1724. For the main references, see: (b) B.-T. Ko and C.-C. Lin, J. Am. Chem. Soc., 2001, 123, 7973; (c) M. H. Chisholm, C.-C. Lin, J. C. Gallucci and B.-T. Ko, Dalton Trans., 2003, 406; (d) M.-L. Hsueh, B.-H. Huang, J. Wu and C.-C. Lin, Macromolecules, 2005, 38, 9482; (e) B.-H. Huang, B.-T. Ko, T. Athar and C.-C. Lin, 
Inorg. Chem., 2006, 45, 7348; (f) C.-A. Huang and C.-T. Chen, Dalton Trans., 2007, 5561; (g) C.-A. Huang, C.-L. Ho and C.-T. Chen, Dalton Trans., 2008, 3502; (h) Y. Huang, Y.-H. Tsai, W.-C. Hung, C.-S. Lin, W. Wang, J.-H. Huang, S. Dutta and C.-C. Lin, Inorg. Chem., 2010, 49, 9416; (i) W.-Y. Lu, M.-W. Hsiao, S. C. N. Hsu, W.-T. Peng, Y.-J. Chang, Y.-C. Tsou, T.-Y. Wu, Y.-C. Lai, Y. Chen and H.-Y. Chen, Dalton Trans., 2012, 41, 3659; (j) N. Ikpo, C. Hoffmann, L. N. Dawe and F. M. Kerton, Dalton Trans., 2012, 41, 6651.

9 For key references with alkaline-earth metals, see: (a) Z. Zhong, P. J. Dijkstra, C. Birg, M. Westerhausen and J. Feijen, Macromolecules, 2001, 34, 3863; (b) M. H. Chisholm, J. Gallucci and K. Phomphrai, Chem. Commun., 2003, 48; (c) M. H. Chisholm, J. C. Gallucci and K. Phomphrai, Inorg. Chem., 2004, 43, 6717; (d) D. J. Darensbourg, W. Choi, P. Ganguly and C. P. Richers, Macromolecules, 2006, 39, 437; (e) Y. Sarazin, R. H. Howard, D. L. Hughes, S. M. Humphrey and M. Bochmann, Dalton Trans., 2006, 340; (f) D. J. Darensbourg, W. Choi, O. Karroonnirun and N. Bhuvanesh, Macromolecules, 2008, 41, 3493; (g) Y. Sarazin, V. Poirier, T. Roisnel and J.-F. Carpentier, Eur. J. Inorg. Chem., 2010, 3423; (h) Y. Sarazin, B. Liu, T. Roisnel, L. Maron and J.-F. Carpentier, J. Am. Chem. Soc., 2011, 133, 906; (i) M. G. Cushion and P. Mountford, Chem. Commun., 2011, 47, 2276; $(j)$ B. Liu, T. Roisnel, J.-P. Guégan, J.-F. Carpentier and Y. Sarazin, Chem.-Eur. J., 2012, 18, 6289.

10 F. M. Kerton, C. M. Kozak, K. Luttgen, C. E. Willans, R. J. Webster and A. C. Whitwood, Inorg. Chim. Acta, 2006, 359, 2819.

11 (a) M.-L. Shueh, Y.-S. Wang, B.-H. Huang, C.-Y. Kuo and C.-C. Lin, Macromolecules, 2004, 37, 5155; (b) J. Wu, Y.-Z. Chen, W.-C. Hung and C.-C. Lin, Organometallics, 2008, 27, 4970; (c) J. Ejfler, K. Krauzy-Dziedzic, S. Szafert, L. B. Jerzykiewicz and P. Sobota, Eur. J. Inorg. Chem., 2010, 3602.

12 (a) C. M. Silvernail, L. J. Yao, L. M. R. Hill, M. A. Hillmyer and W. B. Tolman, Inorg. Chem., 2007, 46, 6565; (b) J. Ejfler, S. Szafert, K. Mierzwicki, L. B. Jerzykiewicz and P. Sobota, Dalton Trans., 2008, 6556.

13 H.-Y. Chen, L. Mialon, K. A. Abboud and S. A. Miller, Organometallics, 2012, 31, 5252.

14 (a) C. K. Williams, N. R. Brooks, M. A. Hillmyer and W. B. Tolman, Chem. Commun., 2002, 2132; (b) S. Dagorne, F. Le Bideau, R. Welter, S. Bellemin-Laponnaz and A. Maisse-François, Chem.-Eur. J., 2007, 13, 3202; (c) J.-T. Issenhuth, J. Pluvinage, R. Welter, S. BelleminLaponnaz and S. Dagorne, Eur. J. Inorg. Chem., 2009, 4701; (d) G. Labourdette, D. J. Lee, B. O. Patrick, M. B. Ezhova and P. Mehrkhodavandi, Organometallics, 2009, 28, 1309; (e) Y. Sarazin, D. Roşca, V. Poirier, T. Roisnel, A. Silvestru, L. Maron and J.-F. Carpentier, Organometallics, 2010, 29, 6569; (f) H.-J. Chuang, S.-F. Weng, C.-C. Chang, C.-C. Lin and H.-Y. Chen,
Dalton Trans., 2011, 40, 9601; (g) V. Poirier, T. Roisnel, S. Sinbandhit, M. Bochmann, J.-F. Carpentier and Y. Sarazin, Chem.-Eur. J., 2012, 18, 2998.

15 (a) T. Aida and S. Inoue, Acc. Chem. Res., 1996, 29, 39; (b) N. Ajellal, J.-F. Carpentier, C. Guillaume, S. M. Guillaume, M. Hélou, V. Poirier, Y. Sarazin and A. A. Trifonov, Dalton Trans., 2010, 39, 8363.

16 V. Poirier, T. Roisnel, J.-F. Carpentier and Y. Sarazin, Dalton Trans., 2011, 40, 523.

17 (a) L. Wang and H. Ma, Dalton Trans., 2010, 39, 7897;

(b) L. Wang and H. Ma, Macromolecules, 2010, 43, 6535;

(c) S. Song, X. Zhang, H. Ma and Y. Yang, Dalton Trans., 2012, 41, 3266.

18 N. Ikpo, L. N. Saunders, J. L. Walsh, J. M. B. Smith, L. N. Dawe and F. M. Kerton, Eur. J. Inorg. Chem., 2011, 5347.

19 (a) S. Shanmuga Sundara Raj, M. N. Ponnuswamy, G. Shanmugam and M. Kandaswamy, J. Crystallogr. Spectrosc. Res., 1993, 23, 607; (b) S. Itoh, H. Kumei, S. Nagatomo, T. Kitagawa and S. Fukuzumi, J. Am. Chem. Soc., 2001, 123, 2165.

20 The analogous reactions between $\left\{\mathrm{LO}^{1}\right\} \mathrm{H}$ or $\left\{\mathrm{LO}^{2}\right\} \mathrm{H}$ and $\mathrm{KH}$ yielded insoluble materials which could not be characterized by spectroscopic techniques.

21 For $\mathrm{Ge}^{\mathrm{II}}$ aminophenolate ROP initiators: S. C. Roşca, V. Poirier, T. Roisnel, C. I. Raț, S. Sinbandhit, J.-F. Carpentier and Y. Sarazin, manuscript in preparation.

22 A. W. Addison, T. N. Rao, J. Reedijk, J. van Rijn and G. C. J. Verschoor, J. Chem. Soc., Dalton Trans., 1984, 1349.

23 The following values were determined for TMSS which is considered spherical: $D_{\mathrm{t}}^{\mathrm{TMSS}, \mathrm{CD} 2 \mathrm{Cl} 2}=2.311 \times 10^{-9} \mathrm{~m}^{2} \mathrm{~s}^{-1}$, $c^{\text {TMSS,CD2Cl2 }}=4.993 \AA, D_{\mathrm{t}}^{\text {TMSS,THF-d8 }}=1.187 \times 10^{-9} \mathrm{~m}^{2} \mathrm{~s}^{-1}$, $c^{\mathrm{TMSS}, \mathrm{THF}-\mathrm{d} 8}=4.735 \AA$, using $f^{\mathrm{TMSS}}=1.00$ and $r_{\mathrm{H}}^{\mathrm{TMSS}}=4.28 \AA$. The values of $c^{\text {TMSS,CD2Cl2 }}$ and $c^{\text {TMSS,THF-d8 }}$ were calculated according to

$$
c_{\text {TMSS }}=\frac{6}{1+0.695\left(\frac{r_{\mathrm{H}}^{\text {solv }}}{r_{\mathrm{H}}^{\mathrm{TMSS}}}\right)^{2.234}}
$$

24 The translational diffusion coefficients for $\left\{\mathrm{LO}^{3}\right\} \mathrm{Li}$ and $\mathrm{LiN}\left(\mathrm{SiMe}_{2} \mathrm{H}\right)_{2}$ in $\mathrm{C}_{6} \mathrm{D}_{6}(20.0 \mathrm{mM}$ solutions, $298 \mathrm{~K}$, $400.13 \mathrm{MHz}$ ) were $D_{\mathrm{t}}=1.16 \times 10^{-10}$ and $1.34 \times 10^{-10} \mathrm{~m}^{2} \mathrm{~s}^{-1}$ respectively.

25 Toluene could not be used on account of the poor solubility of the alkaline complexes in this solvent, whereas the use of THF led to extremely slow reactions, most probably owing to competitive coordination of the solvent onto the metal centres.

26 M. Save, M. Schappacher and A. Soum, Macromol. Chem. Phys., 2002, 203, 889.

27 R. K. Dean, A. M. Reckling, H. Chen, L. N. Dawe, C. M. Schneider and C. M. Kozak, Dalton Trans., 2013, DOI: 10.1039/C2DT32682E.

28 Reactions conditions: $1.1 \mathrm{~mL}$ of dichloromethane- $\mathrm{d}_{2}$, $5.0 \mathrm{mg}$ of $3,79.0 \mathrm{mg}$ of $\mathrm{L}-\mathrm{LA}, 2.3 \mu \mathrm{L}$ of $\mathrm{BnOH},[\mathrm{L}-\mathrm{LA}]_{0}=$ $0.5 \mathrm{M},[\mathrm{L}-\mathrm{LA}]_{0}-[3]_{0}-[\mathrm{BnOH}]_{0}=50: 1: 2, T=30{ }^{\circ} \mathrm{C}$. For 
practical reasons (accuracy on the measurements of the reagents), it was not possible to monitor the ideal $1: 1: 1$ reaction.

29 See for instance ref. $8 j$ and the references cited therein, and also: M. Lu, Y. Yao, Y. Zhang and Q. Shen, Dalton Trans., 2010, 39, 9530.

30 B. Liu, T. Roisnel, L. Maron, J.-F. Carpentier and Y. Sarazin, Chem. Eur. J., 2013, DOI: 10.1002/chem.201204340.

31 A. Macchioni, G. Ciancaleoni, C. Zuccaccia and D. Zuccaccia, Chem. Soc. Rev., 2008, 37, 479.

32 F. Perrin, J. Phys. Radium, 1936, 7, 1.
33 (a) H.-C. Chen and S.-H. Chen, J. Phys. Chem., 1984, 88, 5118; (b) E. Yumet, H.-C. Chen and S.-H. Chen, AIChE J., 1985, 31, 76 .

34 (a) D. Zuccaccia and A. Macchioni, Organometallics, 2005, 24, 3476; (b) C. Krempner, M. H. Chisholm and J. Gallucci, Angew. Chem., Int. Ed., 2008, 47, 410.

35 (a) A. Altomare, M. C. Burla, M. Camalli, G. L. Cascarano, C. Giacovazzo, A. Guagliardi, A. G. G. Moliterni, G. Polidori and R. Spagna, J. Appl. Crystallogr., 1999, 32, 115; (b) G. M. Sheldrick, SHELXL-97, Program for Refinement of Crystal Structures, University of Göttingen, Germany, 1997. 